UNIVERSIDADE DE SÃO PAULO

ESCOLA DE EDUCAÇÃO FÍSICA E ESPORTE DE RIBEIRÃO PRETO

Otávio Augusto Gratão

Valores humanos, Jogos Olímpicos e envolvimento: uma pesquisa com os alunos e profissionais de educação física

RIBEIRÃO PRETO 


\title{
VALORES HUMANOS, JOGOS OLÍMPICOS E ENVOLVIMENTO: UMA PESQUISA COM OS ALUNOS E PROFISSIONAIS DE EDUCAÇÃO FÍSICA
}

\author{
OTÁVIO AUGUSTO GRATÃO
}

Dissertação apresentada à Escola de Educação Física e Esporte de Ribeirão Preto da Universidade de São Paulo, para a obtenção do título de mestre em Ciências, Programa de Pós-Graduação Educação Física e Esporte.

Área de concentração: Atividade Física e Esporte

Orientador: Prof. Dr. Claudio Miranda da Rocha 
Autorizo a reprodução e divulgação total ou parcial deste trabalho, por qualquer meio convencional ou eletrônico, para fins de estudo e pesquisa, desde que citada a fonte.

\section{Gratão, Otávio Augusto}

Valores humanos, Jogos Olímpicos e envolvimento: uma pesquisa com os alunos e profissionais de educação física / Otávio Augusto Gratão.

Ribeirão Preto: [s.n.], 2018.

iv, p. 68

Dissertação (Mestrado em Educação Física e Esporte) - Escola de Educação Física e Esporte de Ribeirão Preto da Universidade de São Paulo. Orientador: Prof. Dr. Claudio Miranda da Rocha

1. Megaeventos 2. Legados 3. Valores humanos I. Título. 
Nome: GRATÃO, Otávio Augusto

Título: Valores humanos, Jogos Olímpicos e envolvimento: uma pesquisa com os alunos e profissionais de educação física

Dissertação apresentada à Escola de Educação Física e Esporte de Ribeirão Preto da Universidade de São Paulo, como requisito parcial para a obtenção do grau de Mestre em Educação Física e Esporte.

Aprovado em:

\section{Banca Examinadora}

Prof. Dr.

Instituição:

Julgamento:

Profa. Dra.

Instituição:

Julgamento:

Prof. Dr.

Instituição:

Julgamento: 


\section{AGRADECIMENTOS}

Agradeço primeiro ao professor Claudio Miranda da Rocha por me orientar e pela paciência em ensinar.

Agradeço aos meus pais, Maurício e Lenice, pelo apoio, por sempre me incentivarem a estudar e por terem me ensinado valores que foram fundamentais para me motivarem a desenvolver esse projeto.

Agradeço ao meu irmão Murilo, pelo apoio e amizade.

Agradeço a minha companheira Vivian, por ter me ajudado e motivado do início ao fim desse projeto. 
RESUMO

GRATÃO, Otávio Augusto. Valores humanos, Jogos Olímpicos e envolvimento: uma pesquisa com os alunos e profissionais de educação física. 2018. 68 f. Dissertação (Mestrado em Atividade Física e Esporte) - Escola de Educação Física e Esporte de Ribeirão Preto, Universidade de São Paulo, Ribeirão Preto, 2018.

Uma das principais metas do Movimento Olímpico é o desenvolvimento de valores humanos por meio dos valores olímpicos que são definidos como valores contidos no âmbito olímpico, e mais ainda, os valores de nossa sociedade como um todo, dada a presença e importância do esporte na história e formação da humanidade (BINDER, 2012). Assim, este estudo teve como objetivo descrever a relação entre a percepção que estudantes e profissionais de educação física têm de valores humanos e o envolvimento com os Jogos Olímpicos (JO) Rio 2016. A amostra foi composta por 317 estudantes e profissionais de educação física que responderam a um questionário em que para mensurar a percepção dos valores foi utilizada a Escala de Educação e Valores Olímpicos (EEVO-36) que foi respondida em escala de Likert de 5 pontos e para o envolvimento foram utilizadas escalas de Shank e Beasley (1998) tanto para mensurar envolvimento comportamental como atitudinal. Os resultados mostraram que o valor trabalho em equipe afeta e é afetado por valores de excelência e autocontrole, e também é afetado pelo fator envolvimento atitudinal, contudo, excelência e autocontrole não afetam um ao outro. Desta forma, percebe-se como a variável trabalho em equipe parece ser a variável que conecta as demais. Mediante aos resultados, foi possível concluir que existe uma necessidade de uma estratégia de alavancagem do legado valores humanos voltados para estudantes e profissionais de educação física para que o Movimento Olímpico atinja seu objetivo de disseminar valores humanos por meio dos JO.

Palavras-chave: Jogos Olímpicos. Megaeventos. Legados. Valores humanos. 
GRATÃO, Otávio Augusto. Human values, Olympic Games and involvement: a research with students and professionals in physical education. 2018. $68 \mathrm{f}$. Dissertation (Master in Physical Activity and Sport) - School of Physical Education and Sports of Ribeirão Preto, University of São Paulo, Ribeirão Preto, 2018.

One of the main goals of the Olympic Movement is the development of human values through olympic values. Olympic values are defined as values contained within the Olympic framework, and even more so, the values of our society as a whole, given the presence and importance of sport in the history and formation of mankind (BINDER, 2012). These values seem to be closely related to the activity of physical education professionals. Thus, this study aimed to describe the relationship between the perception that students and professionals in physical education have of human values and involvement with the Rio 2016 Olympic Games (OG). The subjects were 317 students and professionals in physical education. To measure the perception of values, the Olympic Values and Education Scale (EEVO-36) was used, which was answered on a Likert scale of 5 points. For the involvement, scales of Shank and Beasley (1998) were used both to measure behavioral and attitudinal involvement. The results showed that the value of teamwork affects and is affected by values of excellence and self-control. However, excellence and selfcontrol do not affect one another. It was also found that teamwork is affected by the attitudinal involvement factor. In this way, one can see how the variable teamwork seems to be the variable that connects the others. It is concluded that there is a need for a strategy of leveraging the legacy human values aimed at students and physical education professionals so that the Olympic Movement achieves its goal of disseminating human values through the OG.

Keywords: Olympic Games. Megaevents. Legacy. Human values. 


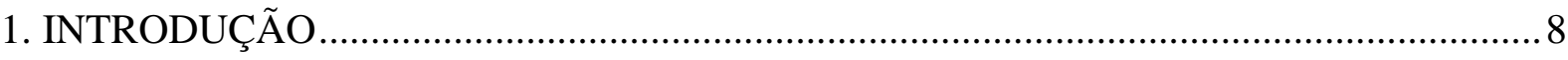

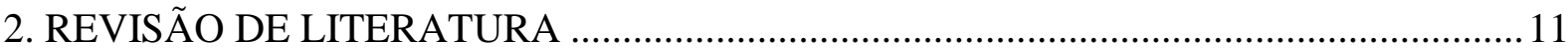

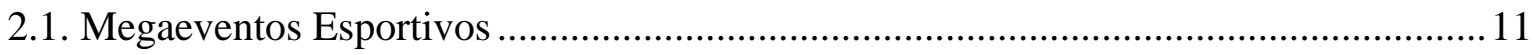

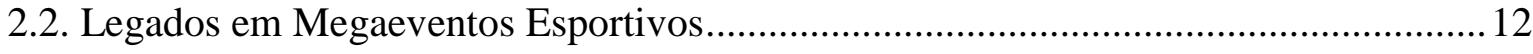

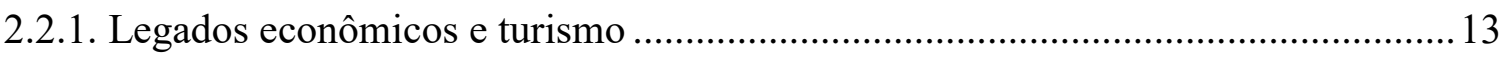

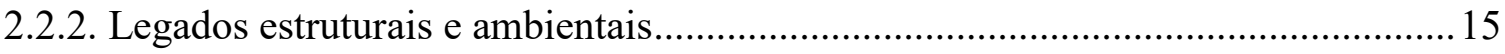

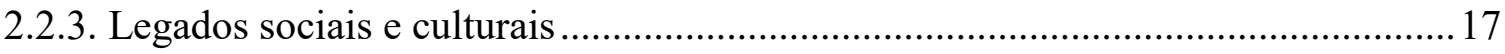

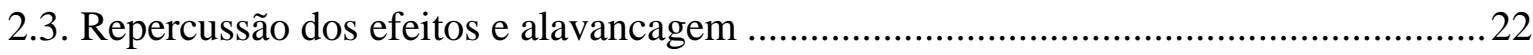

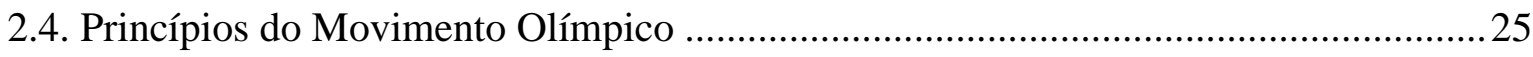

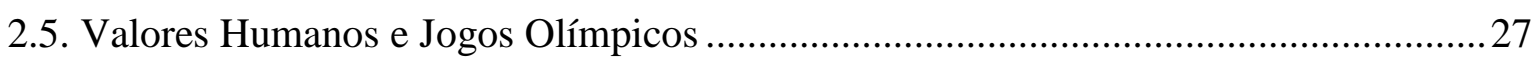

2.6. Relação entre Envolvimento e Valores Humanos .......................................................29

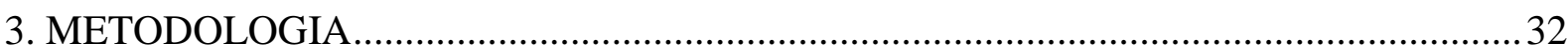

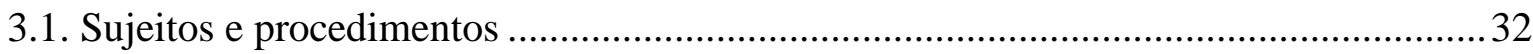

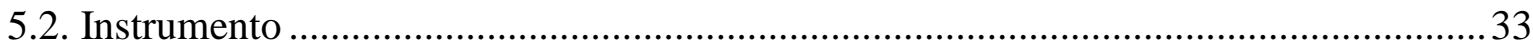

5.2.1. Escala de Educação e Valores Olímpicos (EEVO-36) ........................................... 34

5.2.2. Escala de Envolvimento e Questionário Sobre Hábitos Midiáticos......................... 34

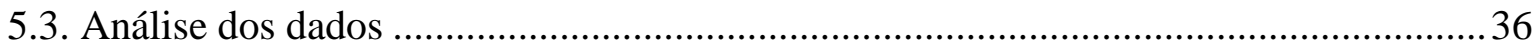

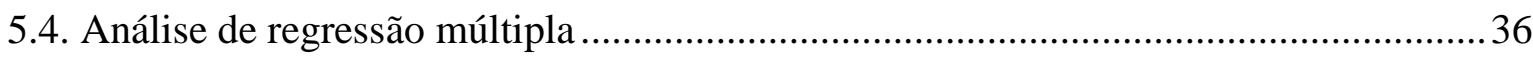

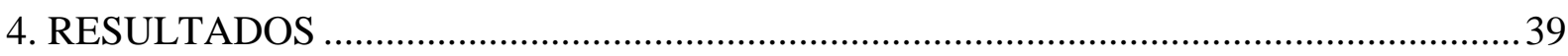

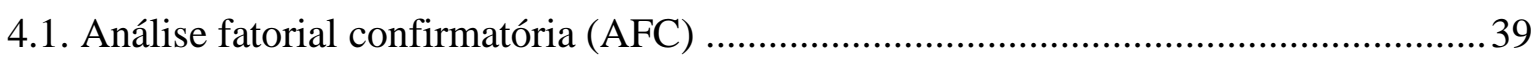

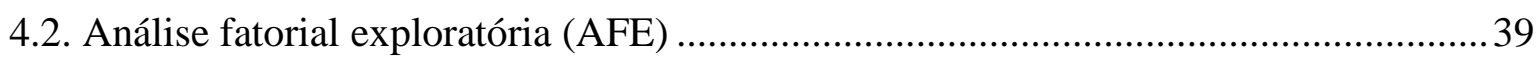

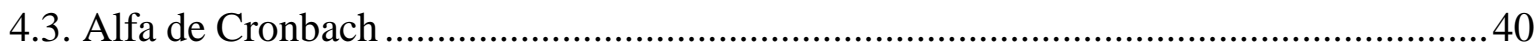

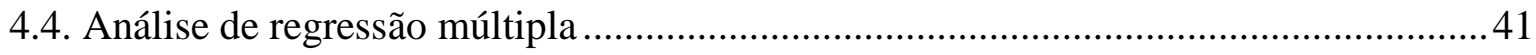

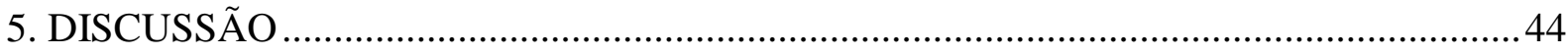

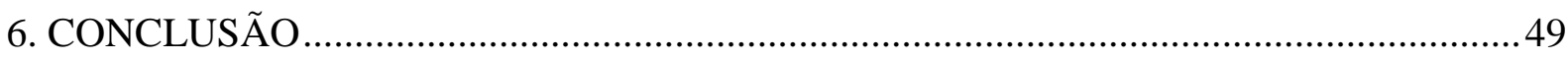

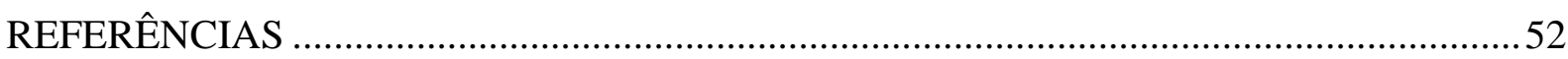

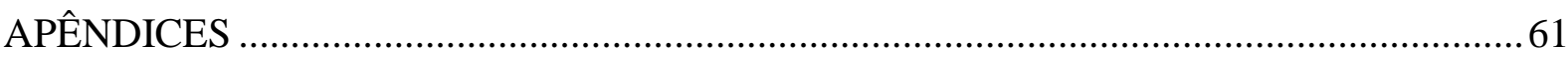




\section{INTRODUÇÃO}

Este estudo tem como objetivo descrever a relação entre a percepção que estudantes e profissionais de educação física têm de valores humanos e o envolvimento com os Jogos Olímpicos Rio 2016. Na presente seção de introdução, será descrito o caminho que foi percorrido até se chegar à lacuna do presente estudo. Na segunda seção será apresentada a revisão de literatura acerca dos principais tópicos da área de pesquisa, tais como: megaeventos esportivos (ME), legados em megaeventos esportivos, repercussão dos efeitos e alavancagem, princípios do Movimento Olímpico, valores humanos e Jogos Olímpicos (JO), relação entre envolvimento e valores humanos. Na terceira seção, serão discutidos os métodos utilizados no presente estudo. Na quarta seção, serão apresentados os resultados. Nas quinta e sexta seções, serão apresentadas a discussão e a conclusão, respectivamente.

Em 2016, a cidade do Rio de Janeiro representou o Brasil ao sediar os primeiros JO da América do Sul. Entretanto, esta não foi a primeira vez que o Brasil teve uma cidade se candidatando à sede dos $\mathrm{JO}$. A primeira candidatura de uma cidade brasileira à sede dos $\mathrm{JO}$ foi para os JO de 1936 com o Rio de Janeiro, já a segunda candidatura à sede dos JO foi em 2000 com a cidade de Brasília. Em seguida, o Rio de Janeiro fez novamente sua candidatura para sediar os JO de 2004, 2012, e 2016, lembrando que em 2012 houve a candidatura de São Paulo que foi retirada pelo Comitê Olímpico Brasileiro (COB) em favor da candidatura da cidade do Rio de Janeiro. Mas foi só na candidatura dos JO de 2016 que o Brasil teve êxito e no dia 2 de outubro de 2009, na $121^{\text {a }}$ Sessão do Comitê Olímpico Internacional (COI) em Copenhague, Dinamarca, o Rio de Janeiro foi escolhido para sediar o XXXI Jogos Olímpicos de 2016. A cidade do Rio de Janeiro tem dois pontos fortes que são de grande importância para sediar um ME: primeiro, o Rio de Janeiro é uma cidade com experiência em receber turistas de várias partes do mundo, ao longo de todo o ano; segundo, a cidade tem um histórico de sediar eventos esportivos importantes como os Jogos Pan-americanos e Parapan-americanos, em 2007.

A cidade sede ou cidade anfitriã, termo utilizado na Carta Olímpica (CO), tem como compromisso cumprir o Contrato da Cidade Anfitriã e tem "a obrigação de se conformar com a $\mathrm{CO}$ e todas as outras regulamentações ou exigências editadas pela Comissão Executiva do COI" (CARTA OLÍMPICA, 2011, p. 79). Desta forma, enquanto a cidade sede tem suas atribuições voltadas ao preparo do local, da infraestrutura e dos espaços dos $\mathrm{JO}$, a "organização dos Jogos Olímpicos é confiada pelo COI ao CON [Comitê Olímpico Nacional] do país da cidade anfitriã, bem como à própria cidade anfitriã" (CARTA OLÍMPICA, 2011, p. 80). Em suma, toda dinâmica olímpica acontece de acordo com a CO e mediante aprovação do COI.

O COI é uma organização não-governamental, sem fins lucrativos, reconhecida pelo 
Conselho Federal Suíço nos termos do acordo assinado no dia $1^{\circ}$ de novembro de 2000 , e tem sua sede em Lausanne (Suíça), a capital Olímpica (CARTA OLÍMPICA, 2011). O objeto do COI é fazer com que os JO aconteçam seguindo a missão, o papel e as responsabilidades que a CO lhe comete (CARTA OLÍMPICA, 2011). De acordo com a CO, cada membro do COI tem como obrigação "conformar-se à CO, ao Código de Ética e outras regras do COI”, assim como, qualquer outro membro que se ligar a realização dos JO (CARTA OLÍMPICA, 2011).

A CO, que norteia as ações do COI e de toda instituição e membro relacionado à realização dos JO, "é a codificação dos Princípios Fundamentais do Olimpismo, das Regras e dos Textos de Aplicação adotados pelo COI” (CARTA OLÍMPICA, 2011, p. 21). Além disso, espera-se que o conteúdo da $\mathrm{CO}$ "permita melhor apreender, interiorizar e vivenciar as regras, os valores e os princípios éticos fundamentais que devem nortear todos os cidadãos, no desporto, como na vida" (CARTA OLÍMPICA, 2011, p. 9). Nesse sentido, O COI tem procurado difundir os valores do Olimpismo por meio dos $\mathrm{JO}$, e para que isso aconteça é fundamental o envolvimento dos espectadores com os JO.

Essa difusão dos valores com os JO é fundamental para o país da cidade anfitriã, pois é importante que os valores transcendam os limites geográficos da cidade sede e tenha repercussão no país todo também. Devido à magnitude dos $\mathrm{JO}$ e à capacidade que os $\mathrm{JO}$ têm de produzir legados (positivos e negativos), acredita-se que aconteça a repercussão dos seus efeitos, assim, fazendo com que esses efeitos cheguem a lugares e pessoas distantes com ou sem relação direta com os Jogos (DECCIO; BALOGLU, 2002; RITCHIE; SHIPWAY; CLEEVE, 2009). Assim, acredita-se que alguns dos legados dos ME não se limitam à uma cidade ou à uma comunidade específica, como o legado promoção dos valores humanos, que pode alcançar pessoas em regiões distantes da cidade sede. Além disso, acredita-se que o envolvimento das pessoas com os JO, assistindo os eventos via mídia, poderia ser capaz de promover os valores difundidos pelo olimpismo em comunidades para além da cidade sede.

Entretanto, ainda não está claro o caráter da relação entre o envolvimento com os JO e a percepção que determinados espectadores têm dos valores humanos, principalmente nas cidades do país sede que não recebem eventos dos JO. Também não está claro a repercussão desses legados para além dos limites geográficos da cidade sede. Diante da realização dos JO, a nação sede toda se envolve com o ME de maneira direta ou indireta, positiva ou negativa, seja por meio de uma relação mais próxima como assistir aos jogos ao vivo, seja por meio de uma relação mais distante como pela internet em breves notícias. Estas relações permitem que os legados não tangíveis (como a promoção de valores humanos) ocorram além das cidades sedes 
por meio da televisão, do computador e dos smartphones, ou simplesmente diante de conversas do dia-a-dia sobre os JO.

Por questão de afinidade ao tema esporte, acredita-se que estudantes e profissionais de educação física podem ser uma parcela da população que tenha um maior envolvimento com os JO e, hipoteticamente, pode ter sido mais afetada pelos valores humanos disseminados pelos JO. Os estudantes e profissionais de educação física representam uma população interessante para se investigar os valores humanos, uma vez que atuam como professores e são responsáveis pela formação e disseminação de valores humanos.

O esporte desenvolvido por meio de valores é de suma importância para a formação dos alunos. O valor do respeito no esporte se manifesta, por exemplo, por meio do "fair play", já a carência do valor do respeito no esporte se manifesta por meio do racismo, como no caso do jogador Grafite que sofreu xingamentos racistas do zagueiro do Quilmes na Libertadores de 2005. Assim como em casos de homofobia, como no caso do jogador de beisebol Yunel Escobar, do Toronto Blue Jays, que pintou uma frase homofóbica no rosto durante jogo nos Estados Unidos. Em ambos os casos houveram punição e repercussão midiática. Como visto, a questão dos valores no esporte é uma questão a ser trabalhado principalmente com os estudantes e profissionais de educação física que participam de forma próxima e efetiva da realização do esporte em suas diversas manifestações. 


\section{REVISÃO DE LITERATURA}

Esta revisão de literatura foi dividida em seis subseções. A primeira subseção trata de aspectos conceituais do tema megaeventos esportivos. A segunda subseção faz uma abordagem de estudos já publicados que investigaram os legados em megaeventos esportivos. A terceira subseção está direcionada aos estudos que abordaram os temas repercussão dos efeitos e alavancagem. A quarta subseção está voltada aos princípios do Movimento Olímpico. A quinta subseção está traz a relação entre os valores humanos e os Jogos Olímpicos. E a sexta subseção relata a relação entre envolvimento e valores humanos.

\subsection{Megaeventos Esportivos}

Entender os ME é essencial quando se trata de Jogos Olímpicos e legados olímpicos, como é o caso do presente estudo. Müller (2015) buscou esclarecer o que faz um evento se tornar um megaevento em suas características e dimensões. Para isso, Müller buscou a definição de megaeventos em estudos como de Maurice Roche que define os megaeventos esportivos como "um evento cultural (incluindo a parte comercial e esportiva) de larga escala, que tem um caráter dramático, apelo popular em massa e significância internacional" (ROCHE, 2000, p. 2). Müller (2015) chegou à uma definição parcimoniosa incorporando elementos encontrados na literatura acadêmica que são necessários para a constituição dos megaeventos. Sendo assim, Müller propôs a seguinte definição consolidada: megaeventos são ocasiões ambulatoriais de uma duração fixa que atraem muitos visitantes, tem um grande apelo midiático, vêm com grandes custos e têm grande impacto na infraestrutura e na população (MÜLLER, 2015).

Dentre as características de um ME, o impacto positivo na infraestrutura e na população é o principal benefício que se espera, tanto na cidade-sede como nas cidades não sedes. Entretanto, sabe-se que os ME proporcionam impactos e legados tanto positivos como negativos. A literatura parece indicar que impactos são imediatos, como por exemplo transtornos causados por obras para melhorar infraestrutura, enquanto legados tem uma natureza de longo prazo, acontecendo por causa dos eventos e durando além do evento em si (HILLER; HANNERS, 2011; PREUSS, 2007). Estes impactos e legados dependerão de diversos fatores como organização, planejamento, apoio popular, controle de gastos, dentre outros. Além disso, sediar ME requer um grande investimento de tempo e dinheiro, principalmente nas transformações estruturais na cidade-sede e em setores diretamente ligados a dinâmica do ME como aeroportos, hotéis e restaurantes. Apesar das informações existentes, até hoje não é possível dizer se os investimentos gerados para os ME produzem um retorno positivo de mesma magnitude (CHALIP et al., 2017). Isso acontece devido à abrangência de 
legados e o caráter de alguns legados, como os legados sociais e culturais, que são intangíveis e de difícil mensuração. Visto isso, os legados são uma das principais razões para se querer sediar um ME como os JO. Isto porque os legados atingem diversos aspectos dentro de uma sociedade podem ter diferentes dimensões como econômica, turismo, ambiental, estrutural, social, cultural e psicológica (ROCHA, 2015). Além desses motivos, também existem interesses políticos que permeiam a busca de sediar os ME, como utilizar a realização dos ME como parte de uma estratégia política para obtenção de poder (GRIX, 2013). Dentro desse contexto, podese dizer que os ME são fenômenos complexos que influenciam e são influenciados por uma série de fatores.

\subsection{Legados em Megaeventos Esportivos}

Em 2002, o COI começou a enquadrar o conceito de legado que tem se tornado uma palavra bastante utilizada pelo próprio COI e pelo Comitês Organizadores dos Jogos Olímpicos (COJOs) (GIRGINOV; HILLS, 2008). Preuss (2007) procurou buscar uma definição que contemplasse a complexidade do conceito de legado em ME. Desta forma, Preuss (2007) definiu legado em ME como "tudo aquilo que é planejado e não planejado, positivo e negativo, tangível e intangível criado para e por um evento esportivo que permanece mais tempo que o evento em si” (p. 211).

Dentro desse conceito, é possível enxergar a infinidade de mudanças que são deixados pelos ME. Entretanto, para investigar os legados alguns pesquisadores dividiram os legados em dimensões mediante uma concepção multidimensional do constructo. Preuss (2007) propõe que os legados dos ME sejam classificados em seis áreas chamando-as de "estruturas do evento", sendo elas: (1) Infraestrutura, (2) Conhecimento, Desenvolvimento de Habilidades e Educação, (3) Imagem, (4) Emoções, (5) Redes de Trabalho e (6) Cultura. Posteriormente, Rocha, Barbanti e Chelladurai (2017) adaptaram essas áreas para seu estudo em sete dimensões de legado: econômico, turismo, ambiental, estrutural, esporte, cultural e psicológico.

Para se ter medida dessas dimensões, muitos estudos encontrados na literatura obtêm suas informações a partir da percepção de legado que determinada população tem em relação ao ME. A percepção de legado que um ME pode trazer a um país, ou a uma população em especial, são informações que podem ajudar os organizadores dos ME durante o processo de preparação para sediar (KIM; PETRICK, 2005). A questão da percepção que os residentes de uma cidade ou de um país sede têm sobre os legados de um ME é ainda mais importante se considerarmos o fato de que muitas vezes quem financia este tipo de evento é o setor público (PREUSS; SOLBERG, 2006). Kim, Gursoy e Lee (2006) revelaram que a percepção de impacto dos residentes da Coréia do Sul em relação aos jogos da Copa do Mundo de 2002 mudaram 
drasticamente após os jogos. Antes dos jogos, os residentes mantinham altas expectativas sobre o evento em relação aos benefícios econômicos e culturais para a comunidade, apesar deles estarem conscientes do fato que estes benefícios viriam com um custo bem alto (KIM; GURSOY; LEE, 2006). Já após o evento, eles perceberam que os benefícios gerados pela Copa do Mundo foram menores que os esperados, especialmente os benefícios econômicos que foram um grande desapontamento para os residentes (KIM; GURSOY; LEE, 2006).

Devido à diversidade dos legados em $\mathrm{ME}$, é preciso que alguns destes sejam estabelecidos como prioritários pelo Comitê Organizador para que se tenha sucesso no planejamento e realização das ações. Segundo o dossiê de candidatura do Rio 2016 (DOSSIÊ RIO 2016, 2009), o Plano de Legado dos Jogos Rio 2016 está centrado em quatro prioridadeschave, que são completamente integradas ao planejamento de longo prazo do Rio: juventude e educação, transformação da cidade, inserção social (habitação, treinamento e emprego) e esportes.

\subsubsection{Legados econômicos e turismo}

Visto que o aspecto econômico é bastante preocupante tanto para a sociedade como para autoridades políticas, ele se tornou um objeto de estudo bastante visado no meio acadêmico. A realização dos JO é de grande interesse para o setor econômico do país já que eles estimulam a economia do país, isto é, a economia da cidade sede e até mesmo de cidades não sede. Quando a realização dos JO é analisada em relação aos seus efeitos sob a comunidade (em um nível local, estadual ou nacional) os JO podem ser considerados uma ameaça devido aos altos investimentos de recursos financeiros do setor público para a realização dos JO. É de inteira responsabilidade da cidade e nação sede cobrir todo os gastos necessários para o desenvolvimento da infraestrutura esportiva. Ritchie, Shipway e Cleeve (2009) relatam que as autoridades políticas tendem a mostrar grande interesse em critérios econômicos, isso devido a três razões principais. Primeira, os aspectos econômicos são os principais em termos de avaliações para se justificar sediar os eventos (RITCHIE; SHIPWAY; CLEEVE, 2009). Segunda, os aspectos econômicos são mais tangíveis e mensuráveis (RITCHIE; SHIPWAY; CLEEVE, 2009). Terceira, os aspectos econômicos tendem a ser considerados fatores positivos, portanto sua mensuração é encorajada (RITCHIE; SHIPWAY; CLEEVE, 2009).

Uma vez que os residentes das cidades sede de ME percebem que o benefício será grande, o custo das instalações não aparenta ser tão grande (KIM; GURSOY; LEE, 2006). Entretanto, se os residentes perceberem que os benefícios gerados são significantemente abaixo do esperado, pode haver uma mudança de percepção dos residentes em relação ao custo/benefício (KIM; GURSOY; LEE, 2006). Esse tipo de mudança de percepção é que pode 
levar os residentes a acreditar, em um momento pós-evento, que os custos das construções e instalações públicas foram maiores do que eles esperavam (KIM; GURSOY; LEE, 2006). Isso leva à uma percepção negativa dos residentes em termos econômicos em relação aos ME (KIM; GURSOY; LEE, 2006). Assim, um bom retorno financeiro dos recursos investidos é crucial para uma percepção positiva das comunidades sede dos ME assim como muitos outros tipos de festivais e eventos (KIM; GURSOY; LEE, 2006).

Outro legado que se apresenta como um dos principais é o do turismo, sendo um dos setores que recebem maior contribuição com a realização dos ME. Os ME influenciam no aumento do fluxo de turistas que viajam com destino aos jogos, mas também influenciam no comportamento de alguns turistas que aproveitam a oportunidade para conhecer os pontos turísticos das cidades sede ou até mesmo do país. Além disso, a realização dos ME coloca em evidência os pontos turísticos da cidade sede na mídia internacional, proporcionando um legado a respeito da imagem do país e da cidade sede. Dada a importância desse fato, Fourie e Gallego (2011) procuraram mensurar o aumento de turistas que chegaram no país sede de diferentes ME (de JO a Copa do Mundo da FIFA - Fédération Internationale Football Association) entre 1995 e 2006. De maneira geral, os resultados desse estudo sugeriram que os ME promoveram o turismo, entretanto o aumento na quantidade de turistas dependeria do tipo de ME, dos países participantes e se o evento é realizado durante a época de alta ou baixa temporada (FOURIE; GALLEGO, 2011). Um importante dado deste estudo foi o fato de que o turismo dos países participantes aumentou mais do que o turismo dos países que não participaram dos ME, após o período dos eventos, mostrando assim uma possível relação entre a realização do evento e uma melhora no setor do turismo a médio e longo prazo.

Rocha e Fink (2017) tiveram como objetivo em sua pesquisa descrever os impactos da interação entre, por um lado, a imagem da marca dos JO e o Brasil (como um destino turístico), e por outro lado, as intenções de assistir aos JO do Rio 2016 e de visitar o país após o evento. Para isso, os autores utilizaram uma amostra de 722 adultos americanos, a maioria deles $(82,2 \%)$ com pelo menos uma experiência de viagem internacional. Os resultados mostraram que a interação entre a hospitalidade associada com a hospitalidade dos $\mathrm{JO}$ e a hospitalidade do Brasil afeta positivamente as intenções de visitar o país depois dos JO. Na segunda parte do estudo de Rocha e Fink (2017), foram conduzidos 5 grupos focais com estudantes de pósgraduação em gestão esportiva $(n=23)$ que indicaram que a associação entre a marca Olímpica deve trazer menos ganhos para o turismo brasileiro que o esperado. Tanto os dados qualitativos, quanto os dados quantitativos deste estudo indicam que a associação da marca Brasil com a marca JO deve trazer menos benefícios para o país sede dos JO de 2016 do que seria esperado. 
Um detalhe importante deste que acrescentou à literatura é que os autores se preocuparam em verificar as intenções das pessoas viajarem ao país sede (Brasil) após os JO e não durante o evento. ME têm se mostrado bastante eficientes para atrair turistas durante o evento. Isto é o que a literatura em turismo associado ao esporte chama de efeito de atração (KIM; CHALIP, 2004). No entanto, para que esta atração se torne um legado, ela tem que acontecer para além do evento (PREUSS, 2007).

\subsubsection{Legados estruturais e ambientais}

A abertura do Rio 2016 com bilhões de espectadores em todo o mundo, teve um compromisso de caráter ambiental e passou uma mensagem de conscientização para o mundo inteiro. Cada um dos atletas que participou da cerimônia de abertura recebeu uma semente ao entrar no campo e ao final do desfile os atletas depositavam a semente em um pequeno vaso. Ao todo foram plantadas 207 espécies diferentes de árvores, cerca de 15 mil sementes, que futuramente darão origem a Floresta dos Atletas no Complexo Esportivo de Deodoro. O caráter voltado para o meio ambiente da abertura dos JO não foi um acontecimento isolado dentro do contexto olímpico do Rio 2016, pois outros projetos foram realizados paralelamente como o projeto “Abraça - Sustentabilidade" (ABRAÇA, 2016) que tem como proposta promover, por meio de programas, a sustentabilidade além do período de realização dos JO. Nesse sentido, os objetivos do projeto "Abraça - Sustentabilidade" foram: (1) estabelecer um padrão de sustentabilidade para a realização de eventos; (2) inserir a sustentabilidade no DNA do desenvolvimento dos Jogos; (3) servir de exemplo de boas práticas sustentáveis; (4) ser transparente mediante o diálogo com a sociedade (ABRAÇA, 2016). O projeto "Abraça Sustentabilidade" conta com parcerias para contemplar a proposta de realizar JO sustentáveis, como o Programa das Nações Unidas para o Meio Ambiente, o Sebrae - Micro e pequenas empresas fornecedoras do Rio 2016 e a FSC - madeira certificada (ABRAÇA, 2016). Estas parcerias têm o objetivo de apoiar a organização dos JO em suas ações, assim, contribuindo em "expertise" em sustentabilidade, fornecimento de materiais sustentáveis e capacitação dos "stakeholders" (ABRAÇA, 2016).

$\mathrm{Na}$ literatura científica, alguns estudos têm se direcionado para o caráter ambiental e estrutural dos JO com a finalidade de explorar esses aspectos, principalmente em termos de legados. Collins, Jones e Munday (2009), abordaram o tema sustentabilidade ao ressaltar que a partir do momento que empresas públicas e privadas reconhecem a importância de um desenvolvimento sustentável, o impacto ambiental dos ME começa a demandar mais atenção (COLLINS; JONES; MUNDAY, 2009). Entretanto, os legados ambientais, assim como os legados culturais e sociais, são de difícil mensuração, principalmente de forma quantitativa. 
Collins, Jones e Munday (2009) relataram que as técnicas quantitativas utilizadas que buscam avaliar os impactos ambientais estão fadadas a ser limitadas em seu âmbito, embora seja possível explorar determinados aspectos ambientais mediante essas técnicas possibilitando o acesso a diversos tipos de informações úteis tanto para os organizadores como para o setor público.

Kim, Gursoy e Lee (2006) tiveram como objetivo examinar a percepção do impacto da Copa do Mundo de Futebol de 2002 dos residentes sul-coreanos, os autores identificaram que, segundo os residentes, o "congestionamento do trânsito" foi tido como o maior problema durante os Jogos. Apesar do trânsito ter sido um problema e os residentes apresentarem uma percepção negativa antes da realização da Copa quanto à qualidade da administração do trânsito, a administração do trânsito surpreendeu positivamente e superou as expectativas dos residentes, ocasionando em um percepção pós-Copa melhor que a percepção pré-Copa (KIM; GURSOY; LEE, 2006). Entretanto, como relatado nesse mesmo estudo, é importante ressaltar que o congestionamento do trânsito é algo que é difícil de ser evitado em um certo nível (KIM; GURSOY; LEE, 2006). Também foi relatado que para os sul-coreanos a Copa do Mundo gerou mais benefícios sociais e culturais que benefícios econômicos (KIM; GURSOY; LEE, 2006). Nesse ME em específico, pode ter ocorrido uma divisão dos benefícios econômicos pelo fato de dois países terem sediado o ME em conjunto, o Japão e a Coréia do Sul.

Gaffney (2013) examinou o projeto do Golfe Olímpico a ser implementado no Rio de Janeiro. Para esse estudo de caso, Gaffney (2013) aplicou algumas técnicas da "Análise de Discurso Crítico" no livro de candidatura do Rio 2016. Neste caso, Gaffney (2013) examinou o conteúdo discursivo do livro de candidatura do Rio 2016 ao contar o número de vezes que palavras específicas e inter-relacionadas aparecem no livro de candidatura. A análise de contagem de palavras indicou que o conceito de sustentabilidade está presente, mas em algum momento ele é eclipsado pelos termos "desenvolvimento" ("development") e "meio ambiente" (“environment”) (GAFFNEY, 2013). Entretanto, se as três palavras forem colocadas juntas, elas serão a temática dominante (GAFFNEY, 2013). Apesar disso, o discurso sustentável não estava articulado com o planejamento público ou a política pública no contexto dos ME no Brasil (GAFFNEY, 2013). Gaffney (2013) argumentou que a menos que os detentores de direitos do ME alterassem seus processos de candidatura e seleção, esses eventos inevitavelmente seriam prejudiciais para seus anfitriões. Gaffney (2013) abordou a questão de que nem o COI e nem a FIFA têm medidas de sustentabilidade que incluem planejamento urbano a longo prazo, utilização das arenas esportivas pós-evento, equidade social ou democracia em seus sistemas discursivos. 
Jin, Zhang, Ma e Connaughton (2011) exploraram os níveis de consciência, a percepção de impacto estrutural, o fator atitude, as intenções comportamentais e o comportamento atual em relação a apoiar a iniciativa das Olimpíadas Verde e de apoiar sediar futuramente ME de residentes da cidade de Pequim, cidade sede dos JO, durante o período de gestão do pós-Jogos (JIN; ZHANG; MA; CONNAUGHTON, 2011). O termo Olimpíadas Verde surgiu a fim de destacar a preocupação ambiental presente na realização dos JO de Pequim 2008. Jin et al. (2011) encontraram em seus resultados que as intenções comportamentais, o fator atitude, e os fatores de percepção tem efeitos diretos e mediados no comportamento atual em relação a apoiar a iniciativa das Olimpíadas Verde e de apoiar sediar futuramente ME. Entretanto, o fator consciência não foi um preditor de comportamento atual em relação a apoiar a iniciativa das Olimpíadas Verde (JIN; ZHANG; MA; CONNAUGHTON, 2011).

Watt (2013) investigou à experiência de deslocamento de londrinos do leste de baixa renda devido aos JO de 2012. Watt (2013) começa descrevendo o contexto geral da regeneração relacionado com a habitação, incluindo o papel reduzido da habitação social, especialmente a habitação pública em Londres. Em seguida, o autor estabelece uma estrutura para entender como a regeneração e o deslocamento conduzidos pelo estado estão interligados, bem como a forma como esses processos foram contestados. Watt (2013) examinou essas questões tendo como referência o estudo de caso de habitantes de dois lugares de classe trabalhadora em Londres uma na vila de Newham, e uma vila olímpica anfitriã. O primeiro estudo de caso baseia-se no estado de Carpenters, um município em Stratford, que enfrenta uma potencial demolição, e o segundo se concentra em jovens que vivem em uma unidade de habitação temporária. Esses estudos de caso ilustraram como os Jogos Olímpicos de 2012, ao lado de outros esquemas de regeneração, mudaram a natureza do espaço e do lugar na perspectiva dos residentes existentes no leste de Londres (WATT, 2013). Nenhum dos dois grupos investigados observaram com atenção a regeneração e as mudanças relacionadas às Olímpiadas (WATT, 2013). Em ambos grupos os respondentes pensaram que eles não poderiam estar vivendo em Stratford ou talvez nem em Newham no futuro (WATT, 2013). O deslocamento ocorreu diretamente e indiretamente, pois a área local mudou e os residentes existentes já não sentem que lá é "seu lugar" (WATT, 2013).

\subsubsection{Legados sociais e culturais}

Os legados sociais podem ser definidos como "o conjunto de bens materiais e imateriais gerados a partir de um ciclo virtuoso de desenvolvimento social capaz de incluir a valorização da vida e da dignidade humana" (CADERNO LEGADOS SOCIAL, s/d, p. 10). Como legados sociais materiais entende-se os projetos como de urbanização de favelas, implantação de redes 
de água, esgoto, saneamento e iluminação, construção de moradias, escolas, centros de saúde, praças, parques e outros tipos de áreas de lazer e melhoria do sistema de transporte. Como podese notar, muitas vezes legados sociais materiais se confundem com legados de infraestrutura. Como legados sociais imateriais entende-se as mudanças sociais ocorridas mediante as oportunidades e ameaças geradas pela realização dos JO dentro de uma sociedade, por exemplo, o aumento da participação esportiva da população (FRAWLEY; CUSH, 2011; MURPHY; BAUMAN, 2007). Os ME também produzem legados culturais como ideias culturais, identidade cultural e produtos culturais (GRATTON; PREUSS, 2008). A cerimônia de abertura, por exemplo, inclui um aspecto cultural e artístico que é uma exibição condensada da cultura do país sede (GRATTON; PREUSS, 2008). A população da cidade e do país sede também ganham um maior conhecimento sobre a história e a cultura de sua cidade e de seu país, assim como sobre a história e a cultura de outros países (GRATTON; PREUSS, 2008). De uma maneira geral, todo aquele legado que transforma um conjunto de padrões de comportamentos, crenças, conhecimentos e costumes da cidade e do país sede, pode ser considerado um legado cultural. Os legados culturais e sociais se cruzam a todo momento principalmente pelo caráter abrangente que ambos possuem. Nesse sentido, a presente seção trata dos legados culturais e sociais lado a lado, sem se aprofundar na discussão de qual vertente ou dimensão dos legados ele tem maior pertencimento.

Um legado sociocultural chave é o legado de participação esportiva, que foi e é um tema bastante frequente na literatura científica, principalmente após a preparação e realização dos JO de Londres de 2012 (WEED et al., 2015; GIRGINOV; HILLS, 2008). Para se ter mais claro como acontece o processo de iniciação a prática esportiva, em função da realização de $\mathrm{ME}$, alguns autores investigaram esse processo. Weed et al. (2015) apresentaram que existe uma diferença entre comtemplar uma ação e agir, que pode ser explicada mediante o modelo chamado de "transtheoretical model" (PROCHASKA; DICLEMENTE; NORCROSS, 1992). Por este modelo, o processo para chegar à participação, e posteriormente à manutenção da prática de exercício, as pessoas em geral seguem a seguinte ordem: (1) pré-contemplação, (2) contemplação, (3) preparação, (4) ação, (5) manutenção. Na fase da pré-contemplação o indivíduo ainda não considera uma nova possibilidade de comportamento a ser adotada. Por meio do contato com os ME (via TV, rádio ou smartphone) o indivíduo pode passar para a fase da contemplação. Nesta fase o indivíduo é sensibilizado por uma nova possibilidade de comportamento, como a participação esportiva, porém ainda não está pronto para a mudança de comportamento. Na fase seguinte, a preparação, são feitos esforços para que as mudanças aconteçam, assim, conduzindo o indivíduo ao novo comportamento. Nessa fase os ME irão 
ajudar o indivíduo a escolher o caminho, ou seja, o indivíduo escolherá se sua participação esportiva será no vôlei, no basquete, no judô, ou em outra modalidade. Assistindo aos ME, o indivíduo faz um julgamento de qual esporte atende melhor o seu perfil e suas condições de vida. Na fase seguinte, a ação, o indivíduo colocará em prática todo o processo das fases anteriores, a mudança de comportamento se concretiza; por exemplo o indivíduo se matricula e vai em uma aula de basquete. É uma fase de experimentação e adaptação do indivíduo. Assistir aos jogos de basquete nos JO podem servir como um fator motivador para os que estão nessa fase e na fase seguinte, a fase da manutenção. Na fase da manutenção, o novo comportamento é adquirido e é mantido ao longo do tempo, nessa fase o indivíduo trabalha para manter o novo comportamento adquirido.

Weed et al. (2015) apresentaram um outro modelo, o modelo de Funk e James (2001), chamado "psychological continuum model", que define o processo do início do contato com o exercício até chegar a prática do exercício. Este modelo constitui do seguinte processo: (1) consciência da existência, (2) atração, (3) engajamento, e (4) fidelidade à prática. Sediar os ME influenciará principalmente na primeira fase (consciência da existência), isso devido a magnitude dos ME e da capacidade que os ME têm de atingir por meio das ferramentas midiáticas um enorme número de pessoas, seja pela $\mathrm{TV}$, rádio e/ou pela internet e na segunda fase (atração), devido a apresentação do fenômeno esportivo de forma espetacular. Na terceira (engajamento) e quarta fase (fidelidade à prática), os ME servirão como um fator motivador para a iniciação e manutenção da prática esportiva.

Frawley e Cush (2011) mostraram um aumento no número de participantes de rúgbi na Austrália após esta sediar a Copa do Mundo de Rúgbi de 2003. Nesse estudo, os pesquisadores decidiram coletar os dados de registro de membros das organizações de rúgbi do estado e do território encontradas na Austrália. No período de 2003 a 2004, houve um aumento no registro da categoria júnior em $20 \%$, enquanto na categoria sênior houve um aumento de $5.34 \%$. Já no período de 2000 a 2008, os registros da categoria júnior aumentaram $68.23 \%$ no total enquanto na categoria sênior os registros aumentaram $10.5 \%$ no total. Segundo o estudo, o ato de sediar a Copa do Mundo de Rúgbi não foi a única razão do aumento dos registros. Os pesquisadores destacaram a importância do contínuo investimento da ARU (“Australian Rugby Union”) no desenvolvimento de programas de rúgbi que começaram nos anos 90. Este estudo destaca não só a importância de sediar os eventos esportivos para se obter aumento da participação esportiva da população, mas também a importância de preparar um ambiente propício para se aproveitar o máximo que os eventos esportivos têm para oferecer. Isso ocorre também em outros setores influenciados pela realização dos $\mathrm{ME}$, onde há alterações em níveis estruturais, organizacionais 
e culturais de uma cidade, estado e/ou país. Atividades pré-evento são necessárias para se conseguir uma realização com qualidade e obter o máximo de proveito dos legados que os eventos têm a oferecer. Da mesma forma, atividades pós-evento são tão importantes quanto as fases anteriores. Entretanto todas as atividades deverão ser direcionadas para a retenção dos legados positivos e resolução dos legados negativos. Além disso, Griffiths e Armour (2013) ressaltam a importância das aspirações dos legados olímpicos serem mais realistas, por exemplo, sendo baseadas em estruturas esportivas já existentes.

Outro legado sociocultural é o aumento da participação esportiva da população da cidade sede. Na fase de preparação, este era um dos legados centrais nos JO de Londres de 2012, sendo o aumento da participação esportiva o legado que o governo do Reino Unido estava convencido de que iria ser concretizado (GRIX, 2013). Além do possível aumento da participação esportiva, que parece não ter ocorrido na proporção desejada, Grix (2013) pontuou que os JO de Londres de 2012 deixaram um legado de "segurança” Olímpica, sendo um dos JO mais seguros já realizado. Entretanto, os governantes não podem contar unicamente com o status ou com a "inspiração" dos JO para aumentar a participação esportiva da população e devem perseguir de maneira mais proativa este legado (BRETHERTON et al., 2016).

A aposta nos JO de Londres de 2012 era de que os JO promovessem a participação esportiva de todos os grupos em todo o Reino Unido. Girginov e Hills (2008) investigaram a relação entre sediar os JO e a participação esportiva no país sede. Sob a perspectiva de que os legados olímpicos são construídos e não são dados, Girginov e Hills (2008) desenvolveram a partir da literatura acadêmica acerca do tema e de dois estudos de caso originais, e analisaram cinco processos principais envolvidos com a construção de legados: "entendimento do legado", "principal público alvo", "processo de construção do legado chave”, implicações de entrega", “contribuição dos Jogos Olímpicas”. Girginov e Hills (2008) concluíram nesse estudo que atingir uma participação esportiva sustentável continuará a ser um alvo ilusório até que os direitos de diferentes comunidades e esportes sejam reconhecidos. Misener et al. (2015) investigaram dois eventos esportivos de médio porte e examinou o grau em que as organizações locais (esportivas) e os comitês organizadores locais (LOC) tentaram alavancar cada evento esportivo para fins de participação esportiva. Misener et al. (2015) usaram a análise de documentos e as entrevistas semi-estruturadas como métodos que revelaram pressupostos gerais de que os eventos em si são suficientes para gerar resultados de participação, entretanto os resultados poderiam ser otimizados se usadas estratégias de alavancagem adequadas, já que as estratégias de alavancagem estavam ausentes, e apenas algumas táticas foram identificadas (MISENER et al., 2015). Estratégias de alavancagem se refere a uma abordagem estratégica 
para gestão de eventos usada para maximizar os ganhos econômicos, sociais e ambientais do destino pré-estabelecido antes, durante e depois de um evento (BEESLEY; CHALIP, 2011). No caso dos eventos esportivos de médio porte analisados por Misener et al., (2015) a alavancagem poderia vir de uma exposição aumentada através das mídias de forma amplificada, celebrações, demonstrações adicionais do esporte e ensino sobre o esporte. Uma barreira chave assinalada por Misener et al. (2015) para a execução da alavancagem foi a identificação de quem deveria ser o responsável por implementar e executar a estratégia e as táticas de alavancagem. De acordo com os resultados, Misener et al. (2015) identificaram vários "stakeholders" que poderiam fazer isso, como os organizadores de eventos, organizações esportivas e comunidades locais. Estes, ao serem designados para a execução da alavancagem, deveriam encontrar formas de usar os eventos como uma alavanca para o aumento da participação da população no esporte, tornando-se parte de seus esforços totais de marketing (MISENER et al., 2015).

Visto a importância dos legados socioculturais, Rabelo et al. (2016) propuseram a Escala de Educação e Valores Olímpicos (EEVO) um instrumento de medida para a avaliação dos valores olímpicos e humanitários na educação. Essa escala foi desenvolvida por Rabelo e seus colegas, com o objetivo de mensurar aspectos da percepção de alunos e professores da rede pública de educação municipal a respeito da prática esportiva e sobretudo dos valores humanitários inerentes ao contexto olímpicos (RABELO et al., 2016). A escala inicialmente era composta por um conjunto de 104 itens que foram submetidos a avaliação de juízes e a estudos posteriores. A partir deste refinamento, os autores sugeriram uma versão composta por 36 itens, a EEVO-36 (RABELO et al., 2016). Rabelo et al. (2016) tiveram como objetivo estimar as primeiras evidências de validade da estrutura interna e precisão da EEVO-36. Nesse estudo a amostra foi composta por 567 participantes com idades que variavam entre 9 e 62 anos (RABELO et al., 2016). O estudo apresentou estrutura interna composta por três fatores, invariantes entre homens e mulheres, interpretados como "Trabalho em Equipe", "Excelência" e "Autocontrole" (RABELO et al., 2016). Diante disso, Rabelo et al. (2016) concluíram que a EEVO-36 apresenta boas qualidades psicométricas para a avaliação de valores olímpicos e humanitários.

Como é possível ver, existem alguns estudos relacionados aos legados socioculturais, entretanto, alguns legados são mais mensurados na literatura acadêmica como é o caso do legado "participação esportiva", e outros são menos mensurados como é o caso dos "princípios e valores olímpicos". 


\subsection{Repercussão dos efeitos e alavancagem}

Os JO podem deixar um leque de legados na cidade sede, não só legados esportivos, mas também legados sociais, econômicos e ambientais (OLYMPIC LEGACY, 2013). Nesse sentido, ao sediar os JO as cidades sedes têm a oportunidade de criar legados esportivos duradouros que ajudam a promover e desenvolver o esporte não só na cidade sede em si, mas também na região e no país que os jogos irão acontecer (OLYMPIC LEGACY, 2013). Essa transcendência dos limites geográficos acontece não só com os legados esportivos, mas com todos os outros legados. Este fenômeno pode ser chamado de "repercussão dos efeitos", ou "spillover effects". A tradução da palavra inglesa "spillover" se refere a algo que transborda ou que se espalha em outra área. Desta forma, "spillover effects" ou repercussão dos feitos tratase do fenômeno de transcendência dos efeitos de uma dada situação para além de sua área (DECCIO; BALOGLU, 2002; RITCHIE et al., 2009). Ao trazer esse conceito para os ME, pode-se considerar repercussão dos efeitos como todos os efeitos causados pelos ME que se repercutem sem se limitar à cidade sede. Os ME têm como característica a capacidade de apresentar problemas e oportunidades especiais não só à comunidade local, mas também às comunidades periféricas, que podem ser afetadas pelos ME devido ao tamanho do fenômeno (DECCIO; BALOGLU, 2002). Isso é uma oportunidade para as outras cidades no país sede de usar a realização do evento para promover o desenvolvimento em sua região por meio do esporte. A repercussão dos efeitos pode variar bastante e está diretamente ligado às ações e estratégias utilizadas para alavancar e promover esse benefício.

Nesse sentido, os legados não devem ser tratados como meros acasos (CHALIP, 2006), mas sim como oportunidades que podem ser ricas ou pobres em benefícios dependendo de como são conduzidas. Nesse caminho, para que o aproveitamento dessas oportunidades seja otimizado, é importante a implementação e gestão de estratégias que promovam a alavancagem ou "leveraging" desses benefícios provenientes dos ME. O termo alavancagem se refere a uma abordagem estratégica para gestão de eventos usada para maximizar os ganhos econômicos, sociais e ambientais do destino pré-estabelecido antes, durante e depois de um evento (BEESLEY; CHALIP, 2011). Desta forma, os legados causados pelos ME em locais não-sedes dependerão em grande parte das estratégias de alavancagem utilizadas para se retirar o máximo possível de benefícios que estes podem proporcionar. Pesquisas sobre alavancagem têm focado principalmente nas cidades sede, entretanto a alavancagem, quando aplicada de forma eficaz, pode ser útil para as cidades não-sede, assim, ampliando a distribuição de benefícios buscados ao sediar eventos (GARDINER; CHALIP, 2006; KELLETT; HEDE; CHALIP, 2008). Ou seja, estratégias de alavancagem dos legados trazem benefícios tanto para cidades sede como para 
cidades não-sedes, quando aplicadas de maneira eficaz (BEESLEY; CHALIP, 2011). No caso dos Jogos da Comunidade Britânica (“Commonwealth Games”), que aconteceram na cidade de Melbourne em 2006, a cidade sede alavancou o evento de maneira que proporcionou benefícios significantes no setor de turismo. Já outras cidades australianas, fora da região de Melbourne, foram capazes de aplicar táticas de alavancagem gerando benefícios sociais significativos para as comunidades não-sedes (KELLET et al., 2008). Para se ter um exemplo, o governo do estado de Victoria, onde está situada a cidade de Melbourne, deu mais de US\$ 1,7 milhão de equipamentos esportivos usados durante os Jogos da "Commonwealth" para mais de 260 clubes e associações vitorianas. Estes equipamentos variavam de dardos, mesas de tênis de mesa, aros de basquete até equipamentos de levantamento de peso (COMMONWEALTH GAMES, 2017). O caso dos Jogos da Comunidade Britânica de Melbourne em 2006 corrobora com Beesley e Chalip (2011) no sentido de que os benefícios dos eventos podem ser otimizados se um plano e uma implementação estratégica forem empregados para alavancar as oportunidades que o evento oferece.

Um exemplo de estratégia de alavancagem é aproveitar o momento para atrair outros eventos para a cidade e para o país sede. Através de estratégias específicas, gestores do primeiro setor e mesmo do setor privado deveriam atrair outros eventos para a cidade e país sede, com o objetivo de aproveitar a estrutura criada para sediar os JO ou outros ME e movimentar a economia antes e/ou após os Jogos (CHALIP, 2002). No Rio de Janeiro aconteceu a Copa do Mundo de Halterofilismo Paralímpico, realizada antes dos JO de 2016. Este evento teve dois objetivos principais: ser um evento-teste e ser uma etapa classificatória para os Jogos Paralímpicos (JP) de 2016 do Rio de Janeiro. O halterofilismo nos JP tem uma particularidade em relação as outras modalidades dos JP, pois atletas com diferentes tipos de limitações físicas competem entre si, chamando atenção para a aceitação da diversidade. Além de movimentar a cidade sede antes dos JO, o evento serviu para o Comitê Rio 2016 testar os árbitros nacionais e operações de transporte, de montagem de arena e de cerimônias, com hasteamento de bandeiras e premiação em pódio. Outro exemplo de realização de evento como estratégia de alavancagem foi o Torneio Internacional de Basquetebol Feminino, evento preparatório para os JO Rio 2016. Antes dos confrontos finais, o evento-teste teve a disputa de uma partida amistosa de basquetebol em cadeiras de rodas. O objetivo foi testar a acessibilidade da arena e as condições de competição. Esses são exemplos de eventos usados como estratégias de alavancagem associadas aos JO e aos JP do Rio 2016. Nos dois exemplos aqui citados, o caráter social dos legados deixados se faz claro principalmente com a preocupação dos organizadores com a acessibilidade. Isso é visto normalmente com bons olhos pela população, podendo influenciar 
no apoio dessa população ao evento. Esses dois exemplos também servem para ilustrar a possibilidade da realização de eventos com um olhar voltado para a perspectiva social. Estas atividades sociais que giram em torno do evento principal podem agregar valor ao evento, tanto em termos de legados econômicos, por exemplo, utilização dos hotéis e restaurantes pelos espectadores, como em termos de legados sociais, por exemplo aumento do respeito a pessoas com deficiência e legados estruturais, por exemplo, melhoria da acessibilidade (CHALIP, 2006).

De uma maneira geral, os estudos sobre a alavancagem de evento visão identificar e explorar as implementações do evento a fim de otimizar os resultados desejados do evento (CHALIP, 2006). O estudo sobre a alavancagem tem como principal finalidade prática prover informações a respeito de qual estratégia ou tática em particular tem surtido mais efeito (CHALIP, 2006). Para exemplificar, a utilização de estratégias para alavancar eventos podemos citar a cidade de Paramatta que, durante os JO de Sydney 2000, apesar de não sediar nenhum evento, tornou-se um destino popular para os anfitriões e para visitantes durante os JO. Isso devido à atração da cidade que foi o festival de rua que seguia a temática dos JO (CHALIP, 2006). O contínuo festival proporcionou oportunidade substancial para socialização - uma característica que tornou Paramatta um local atrativo durante os JO (CHALIP, 2006). Assim, os legados dos ME dependem de uma variedade de fatores, mas principalmente das ações efetivas para que os legados aconteçam. Desta forma, Chalip (2006), afirma que os eventos não são intervenções por si mesmos, o que realmente importa é se eles são usados estrategicamente, e quão bem essas estratégias são desenvolvidas e implantadas.

Ritchie, Shipway e Cleeve (2009) investigaram em 2007 a percepção dos residentes de Weymouth e Portland na Inglaterra em relação aos impactos dos JO de Londres de 2012, estas duas cidades investigadas sediaram os eventos de vela dos JO de 2012. Ritchie, Shipway e Cleeve (2009) relataram que aqueles residentes que viviam mais perto das arenas olímpicas apoiavam menos a fato de sediar os JO do que aqueles que moram em áreas mais afastadas das arenas esportivas (RITCHIE; SHIPWAY; CLEEVE, 2009). Isso pode acontecer em partes devido aos impactos negativos pontuais, em geral antes do evento, tais como congestionamento do tráfego e problemas de estacionamento, que são identificados pelos residentes como fatores que afetam mais aqueles que moram mais perto das arenas utilizadas (RITCHIE; SHIPWAY; CLEEVE, 2009). Além disso, os autores constataram que aqueles residentes localizados próximos às arenas olímpicas são menos propensos a perceberem os impactos sociais positivos (RITCHIE; SHIPWAY; CLEEVE, 2009). Estes resultados foram confirmados no estudo de Weimar e Rocha (2017), que investigaram o apoio dos residentes da cidade do Rio de Janeiro 
à realização dos JO Rio 2016 e encontraram que aqueles que viviam mais perto das áreas de competição (Barra, Deodoro e Maracanã, principalmente) tendiam a oferecer menos suporte ao evento. Uma possível solução para diminuir a rejeição aos Jogos por parte daqueles que moram perto das arenas (e que são afetados por impactos negativos das obras antes dos Jogos) seria alavancar os legados pré-Jogos nestas áreas. Por exemplo, através de atrações culturais e esportivas que mostrem a importância dos Jogos para as regiões que os abrigam.

Deccio e Baloglu (2002) investigaram a percepção da repercussão dos efeitos dos Jogos Olímpicos de Inverno de 2002 de residentes de uma comunidade não-sede, os fatores que antecedem estas percepções dos impactos, e consequente suporte aos Jogos. Os resultados mostraram que apesar de alguns residentes perceberem que os Jogos trariam oportunidades, a maioria dos residentes não prevê qualquer impacto local proveniente do evento (DECCIO; BALOGLU, 2002). Os resultados encontrados nesse estudo indicaram que os residentes com consciência ambiental não apoiam os Jogos (DECCIO; BALOGLU, 2002). Já aqueles que economicamente dependem do turismo e aqueles que participam de atividades ao ar livre geralmente apoiam os Jogos (DECCIO; BALOGLU, 2002). Por outro lado, o vínculo dos residentes com a comunidade não influenciou na percepção de oportunidades Olímpicas ou no apoio aos Jogos (DECCIO; BALOGLU, 2002). O apoio aos Jogos de 2002 foi significantemente e positivamente influenciado pela percepção de melhoria na repercussão dos benefícios (oportunidades), no ganho econômico e no uso de recursos (DECCIO; BALOGLU, 2002).

Assim, é possível perceber a importância de pesquisas em torno da repercussão dos efeitos dos ME com as comunidades não-sedes para construir conhecimentos a respeito de como aproveitar, alavancar e utilizar as oportunidades que os ME proporcionam.

\subsection{Princípios do Movimento Olímpico}

Para se ter uma ideia do apelo midiático dos JO cerca de seis mil profissionais de imprensa e vinte mil de televisão fizeram a cobertura jornalística, além disso, as cerimônias de abertura e encerramento foram vistas pela televisão por, aproximadamente, 4,5 bilhões de pessoas no mundo todo (COI, s/d). Em relação a dimensão do ME, cerca de 10.700 atletas de 205 nações participaram dos JO, além da participação das 2 delegações especiais (Atletas Olímpicos Independentes e Atletas Olímpicos Refugiados), esses atletas disputaram 306 provas com medalhas divididas em 42 modalidades (COI, s/d). Dessas provas, foram 161 provas masculinas, 136 femininas e 9 mistas (COI, s/d). Outro número que impressionou nos JO do Rio foi o número de ingressos colocados à disposição: 7,5 milhões (COI, s/d). Por fim, outro fato que chamou a atenção foi a participação de cerca de 45 mil voluntários na organização dos 
JO de 2016 (COI, s/d). Para chegar a essa magnitude os JO passaram por diversas mudanças ao longo do tempo, e a principal mudança para que os JO se tornassem como é hoje foi com Pierre de Coubertin que iniciou o Olimpismo Moderno. Pierre de Coubertin nasceu na França em 1863 e dedicou sua vida à reforma da educação e da juventude na França, fascinado pelo sistema educacional inglês, que incluía o esporte no programa de ensino, ele buscou convencer seus contemporâneos na França que o esporte poderia ser benéfico para os jovens e foi dentro desse contexto que Pierre de Coubertin teve a ideia de reviver os Jogos (OLYMPISM AND THE OLYMPIC MOVEMENT, 2013). Foi em 1896, em Atenas, Grécia, que aconteceram os primeiros JO da era moderna (OLYMPIC CHARTER, 2015). De acordo com o documento do Comitê Olímpico Internacional (COI) intitulado "Olympism and the Olympic Movement" (2013), para Pierre de Coubertin os Jogos não eram um fim em si só, mais que isso, eles eram parte de um projeto muito mais amplo que era promover educação por meio do esporte, para isto foram estabelecidos princípios e valores olímpicos que norteiam o Movimento Olímpico.

Os princípios fundamentais do Olimpismo estão presentes na carta Olímpica onde estão codificados os princípios, regras e estatutos sociais adotados pelo COI (OLYMPIC CHARTER, 2015). Além disso, a Carta Olímpica é o documento que governa a organização, ação e operação do Movimento Olímpico. Desta forma, os princípios e valores olímpicos presentes na carta Olímpica norteiam a realização do evento estando em praticamente todos os acontecimentos relacionados ao COI e aos JO (OLYMPIC CHARTER, 2015). Em essência, a Carta Olímpica serve a três propósitos principais: (1) atua como um instrumento básico de natureza constitucional, que apresenta e recorda os princípios fundamentais e os valores essenciais do Olimpismo; (2) serve como um estatuto para o COI; e (3) define os principais direitos recíprocos e obrigações dos três principais constituintes do movimento Olímpico (COI, Federações Internacionais e Comitês Olímpicos Nacionais), assim como do Comitê Organizador dos Jogos Olímpicos - todos estes obrigados a seguir os princípios da carta Olímpica (OLYMPIC CHARTER, 2015). De acordo com a Carta Olímpica, os princípios fundamentais do Olimpismo são sete:

(1) o Olimpismo é uma filosofia de vida que exalta e combina o equilíbrio entre as qualidades do corpo, força de vontade e mente. O que inclui conciliar o esporte com cultura e educação, buscar criar um estilo de vida baseado no prazer do esforço, o valor educacional do bom exemplo, responsabilidade social e respeito aos princípios fundamentais éticos universais;

(2) o objetivo do Olimpismo é o de colocar o esporte a serviço do desenvolvimento harmonioso da humanidade, com a visão de promover uma sociedade pacífica preocupada com a preservação da dignidade humana; 
(3) o movimento Olímpico é a ação combinada, organizada, universal e permanente, executada sob a jurisdição da autoridade do COI, esta ação é de todos os indivíduos e entidades que são inspirados pelos valores do Olimpismo. O movimento Olímpico atinge seu ápice com o encontro de atletas do mundo todo em um grande festival esportivo, os JO;

(4) a prática do esporte é um direito humano. Todo indivíduo deve ter a possibilidade de praticar esporte, sem discriminação de nenhuma espécie e no espírito olímpico, o qual corresponde um entendimento mútuo com um espírito de amizade, solidariedade e "fair play";

(5) as organizações esportivas dentro do movimento Olímpico devem ter os direitos e obrigações da autonomia, o que inclui controlar e estabelecer livremente as regras do esporte, determinando a estrutura e governança de suas organizações, desfrutando do direito de eleições livres de qualquer influência externa e a responsabilidade de assegurar que os princípios de boa governança sejam aplicados;

(6) o aproveitamento dos direitos e liberdade apresentado na carta Olímpica deve ser assegurado sem discriminação de qualquer espécie, como raça, cor, sexo, orientação sexual, linguagem, religião, opinião política ou outra opinião, origem social ou nacional, propriedade, nascimento ou outro status;

(7) o pertencimento ao movimento Olímpico requer cumprimento da carta Olímpica e reconhecimento pelo COI.

Estes princípios fundamentais contidos na Carta Olímpica foram baseados em um conjunto de valores humanos chamados de valores olímpicos, que são a referência fundamental do Movimento Olímpico até os dias atuais (RUBIO, 2009).

\subsection{Valores Humanos e Jogos Olímpicos}

Um dos teóricos pioneiros em investigar a parte conceitual dos valores humanos foi Rockeach (1973). A formulação do conceito do termo valores humanos por Rockeach (1973), foi guiada por cinco premissas sobre a natureza dos valores humanos: (1) o número total de valores que uma pessoa possui é relativamente pequeno; (2) todas as pessoas independente do lugar possuem os mesmos valores em diferentes níveis; (3) valores são organizados em sistemas de valores; (4) os antecedentes dos valores humanos podem ser traçados pela cultura, pela sociedade e suas instituições, e pela personalidade; e (5) as consequências dos valores humanos serão manifestados em praticamente todo fenômeno que os cientistas sociais podem considerar importante investigar e compreender. Nesse sentido, para Rockeach (1973), valores são crenças duradouras de um modo de conduta específico ou estado final de existência pessoalmente ou socialmente preferível a um outro (geralmente) oposto. Muitos estudos acerca do tema valores têm sido feitos desde a elaboração deste conceito por Rockeach (1973). Oliveira e Tamayo 
(2002), por exemplo, investigaram a relação entre valores e atitudes/comportamentos, a fim de identificar se os valores são preditores de atitudes e comportamentos, tais como escolha ocupacional, orientação política, religião, estilo de vida, entre outros. Em conclusão, Oliveira e Tamayo (2002) pontuaram que, de acordo com as evidências encontradas na literatura acadêmica, o poder preditor dos valores sobre as atitudes e os comportamentos vem sendo confirmado por diversos autores. Ou seja, os dois pressupostos básicos sobre valores é que estes guiam as ações tanto quanto as atitudes e que os valores são mais anteriores do que atitudes (OLIVEIRA; TAMAYO, 2002).

Visto isso, tratar de questões vinculadas aos valores olímpicos é, acima de tudo, levantar à discussão a respeito dos valores humanos contido no âmbito esportivo, na prática de toda e qualquer atividade física, e mais ainda, na nossa sociedade como um todo, dada a presença e importância do esporte na história e formação da humanidade (BINDER, 2012). Visto a relevância dos valores dentro de um grupo, uma das principais metas do Movimento Olímpico é o desenvolvimento de valores humanos que norteiem o comportamento dos indivíduos e da sociedade (RUBIO, 2009). Nesse sentido, o COI tem idealizado uma estratégia destinada a manter os jovens interessados no esporte, encorajando-os a praticar esporte e promovendo os valores olímpicos através do esporte (OVEP, 2014). De acordo com o "Olympic Value Education Programme" (OVEP, 2014), são três os valores olímpicos:

- Excelência: Este valor significa fazer o melhor que podemos, no campo de jogo ou na nossa vida profissional. O importante não é vencer, mas participar, fazer progressos e apreciar a combinação saudável de corpo, mente e vontade.

- Amizade: Este valor encoraja a todos a ver o esporte como um instrumento para a compreensão mútua entre as pessoas e entre pessoas de todo o mundo.

- Respeito: Este valor inclui o respeito por si mesmo e seu corpo, por outras pessoas, por regras e regulamentos, pelo esporte e pelo ambiente.

Rubio (2012) apresenta, além desses três valores, mais quatro valores que baseiam e fundamentam o Olimpismo em si, são eles: coragem, determinação, inspiração, igualdade. Pode-se encontrar também esses sete valores divididos, sendo três (amizade, excelência e respeito) classificados como valores olímpicos e sendo quatro (coragem, determinação, inspiração e igualdade) classificados como valores paralímpicos (COI, s/d). Pode-se também encontrar em algumas ocasiões esses valores apresentados com outra nomenclatura a fim de se adaptar ao público-alvo (COI, s/d). Como é o caso do programa de educação olímpica chamado “Transforma” que tentou apresentar os Jogos Olímpicos e Paralímpicos Rio 2016 para as unidades escolares de todo o Brasil, neste caso, os valores olímpicos e paraolímpicos 
precisaram de uma adaptação de nomenclatura para serem inseridos mais facilmente no âmbito escolar (COI, s/d). Assim, os sete valores foram adaptados para "alegria do esforço", "jogo limpo", "respeito pelos outros", "busca pela excelência" e "equilíbrio entre corpo, vontade e mente" (COI, s/d). Entretanto, é importante lembrar que, apesar dos valores olímpicos que fundamentam o Olimpismo serem apresentados de diferentes formas, estes valores são, antes de tudo, valores humanos (RUBIO, 2012). Desta forma, apesar de dividirem os valores em olímpicos e paralímpicos, os valores amizade, excelência e respeito estão presentes nos Jogos Paraolímpicos e na sociedade como um todo, assim como os valores coragem, determinação, inspiração e igualdade estão presentes nos Jogos Olímpicos e na sociedade como um todo. Por fim, vale ressaltar que estes valores funcionam como um "código de conduta" do Movimento Olímpico e norteiam as atitudes e ações de todos os envolvidos nas atividades olímpicas, sejam elas competitivas, administrativas ou voluntárias (RUBIO, 2009).

\subsection{Relação entre Envolvimento e Valores Humanos}

Para Beaton, Funk e Alexandris (2011), envolvimento é um constructo multifacetado que representa o nível que a participação na atividade esportiva se torna um componente central da vida da pessoa e promove tanto os valores simbólicos, como os valores hedônicos. As facetas do envolvimento para essa definição de Beaton, Funk e Alexandris (2011) são "centralidade", "valor simbólico" e "valor hedônico". Estas três facetas do envolvimento juntas podem ser usadas para criar um perfil de envolvimento que serve para examinar o nível de envolvimento do indivíduo com o esporte e para ajudar a distinguir atitudes e comportamentos dos consumidores esportivos (BEATON; FUNK; ALEXANDRIS, 2009). Pensando na definição de Beaton, Funk e Alexandris (2011), pode-se entender que o envolvimento com um objeto esportivo corresponde ao nível com que esse processo de participar/acompanhar o esporte torna um componente preferencial em sua vida durante o período em que este é realizado, além de promover valores hedônicos ao consumidor do esporte.

Já para Zaichkowsky (1985), o envolvimento é uma percepção do indivíduo da relevância de um objeto baseado em necessidades, valores e interesses inerentes. Na definição de Zaichkowsky (1985) é possível perceber a importante influência dos valores sobre o envolvimento do indivíduo a determinado objeto. De acordo com essa definição, o constructo "valores humanos" antecede o constructo do "envolvimento". Entretanto, a relação inversa também pode ocorrer, já que o envolvimento com os JO pode influenciar nos valores do indivíduo. Por exemplo, os JO são realizados com base em seus próprios valores e a disseminação desses valores é um dos objetivos do Movimento Olímpico. Sendo assim, esperase que quanto maior o envolvimento das pessoas com os JO, maior será o desenvolvimento 
desses valores pelo indivíduo. Em outras palavras, se o Movimento Olímpico tem sido eficaz em disseminar os valores olímpicos através dos JO, um maior envolvimento e apreciação dos JO deveria levar a uma percepção superior destes valores.

Voltar o olhar para o envolvimento dos consumidores do esporte com os JO possibilita enxergar alguns aspectos importantes principalmente para os organizadores dos ME e para os políticos, que usam os JO como catalizador para a promoção da imagem do país ou cidade sede que eles estão governando. Uma das afirmativas encontradas na literatura acadêmica é o fato de que o consumidor que indica alto nível de envolvimento é mais provável que se torne leal às atividades relacionadas ao esporte e resista à mudança de produto, isso quando comparado com um consumidor com baixo nível de envolvimento (MCGEHEE; YOON; CARDENAS, 2003). Para MccGehee, Yoon e Cardenas (2003) o constructo envolvimento se correlaciona com o constructo lealdade à atividade.

Filo, Funk e O’Brien (2009) investigaram eventos de corrida de rua para consumidores do "esporte participação" e verificaram que conduzir um evento bem organizado que atenda às necessidades e desejos dos corredores é importante tanto para estimular a prática de exercícios físicos, quanto para gerar satisfação nas pessoas (clientes) que pagam para participar de tais eventos. Para Filo, Funk e O'Brien (2009), no contexto do evento de corrida de rua, o envolvimento com o evento ao participar da corrida e o fato dessa experiência atender às necessidades e desejos do consumidor são fatores importantes para a mudança de comportamento e afetam a percepção dos consumidores em relação a satisfação. De modo similar, pode-se esperar que caso os JO sejam bem organizados e transmitam valores positivos a quem os assiste, o envolvimento com os $\mathrm{JO}$ pode alterar atitudes e comportamentos dos seus consumidores.

Havitz e Mannell (2005) classificaram o envolvimento em duas categorias: envolvimento duradouro e envolvimento situacional. O envolvimento é classificado como duradouro quando é um envolvimento estável através do tempo e de situações (HAVITZ; MANNELL, 2005), por exemplo, o indivíduo que toda segunda-feira joga futebol com os amigos. Por outro lado, o envolvimento é situacional quando é um envolvimento temporário e dependente de contexto (HAVITZ; MANNELL, 2005), por exemplo, o indivíduo que só vai jogar futebol com os amigos se o melhor amigo dele também for jogar.

Segundo Funk, Ridinger e Moorman (2004) a aplicação do constructo envolvimento para investigar espectadores esportivos e fãs esportivos poderá prover um entendimento mais completo de quais motivos, estímulos e situações norteiam a formação de comportamento e atitude. O envolvimento comportamental diz respeito, por exemplo, ao comparecimento ao 
evento, à compra de determinado produto e o consumo de média (FUNK; RIDINGER; MOORMAN, 2004), nesse sentido, o envolvimento comportamental sai do campo das ideias e se concretiza em uma realização prática, como assistir aos JO nas arenas, na TV ou na internet. Já o envolvimento atitudinal diz respeito a um constructo mais abstrato como preferências, comprometimento e lealdade em relação a um objetivo de consumo (FUNK; RIDINGER; MOORMAN, 2004).

O envolvimento se relaciona com diversas atitudes e diversos comportamentos das pessoas. Assim, pode influenciar constructos que influenciam no comportamento do consumidor do esporte. A dinâmica em torno do constructo envolvimento é bastante complexa, o que gera necessidade de investigações nessa área principalmente para se entender melhor a relação entre o constructo envolvimento e atitudes e comportamentos das pessoas.

Existe na literatura uma ausência de estudos que investiguem a relação entre o envolvimento com os $\mathrm{ME}$ em geral, e com os $\mathrm{JO}$ em específico, e possíveis legados não tangíveis destes. Para a presente pesquisa, optou-se por verificar-se apenas um destes legados não tangíveis: o desenvolvimento dos valores dos valores humanos (olímpicos). Para se verificar esta relação, o constructo valores humanos foi operacionalizado a partir da percepção que as pessoas têm da importância destes para sua atuação profissional. Desta forma, espera-se descrever se um maior envolvimento com os JO Rio 2016 poderia indicar uma maior percepção de valores humanos em atuação profissional, o que representaria um importante legado não tangível para o país sede. 


\section{METODOLOGIA}

A coleta de dados foi realizada no primeiro semestre de 2017, entre seis meses e um ano após os JO Rio 2016. Os dados foram coletados após os JO para que o envolvimento pudesse ser mensurado, além disso, não seria oportuno esperar muito tempo após os JO porque os participantes poderiam esquecer o quanto os $\mathrm{JO}$ foram importantes para eles ou o quanto que eles se envolveram com os JO em termos de tempo gasto assistindo ao ME.

\subsection{Sujeitos e procedimentos}

A população investigada no presente estudo foi composta por estudantes e profissionais da área de Educação Física da cidade de Ribeirão Preto do estado de São Paulo. A escolha de uma cidade não sede teve como finalidade verificar a repercussão dos efeitos dos JO para além das fronteiras de sua cidade/estado sede. Ribeirão Preto tem como característica uma população de grande porte, cerca de 674 mil habitantes em 2016 e tem cinco cursos superiores em educação física (Universidade de Ribeirão Preto, Centro Universitário Moura Lacerda, Universidade Paulista, Centro Universitário Estácio Uniseb e Escola de Educação Física e Esporte de Ribeirão Preto da Universidade de São Paulo), que indica a possibilidade de se ter muitos estudantes e os profissionais da área de educação física respondentes. Esta cidade tem também se destacado no cenário do esporte competitivo, cedendo vários atletas no cenário nacional e internacional, até mesmo nos JO. Como exemplo, pode-se citar Sócrates, Raí e Diego Ribas (futebol), Laís Souza e Francisco Barreto (ginástica artística), Fernanda Venturini (voleibol) e Gustavo Borges (natação). A cidade também apresenta um significativo poder econômico e de desenvolvimento, o que diminui fatores externos que possam interferir nos interesses da presente investigação como a falta de TV ou internet para ter acesso aos JO Rio 2016.

O contato com os estudantes e os profissionais da área de educação física para a pesquisa aconteceu inicialmente mediante o contato com as universidades locais. O primeiro passo foi entrar em contato com os coordenadores dos cursos a fim de apresentar a pesquisa e solicitar a participação dos alunos e ex-alunos (profissionais). A partir deste contato, três caminhos foram seguidos. O primeiro foi pedir uma relação com o e-mail dos alunos e dos egressos das universidades que concordassem em participar. Para aquelas universidades que se recusaram a fornecer os e-mails, pedimos que as próprias universidades divulgassem/enviassem o link do questionário online. Nos casos em que esta alternativa também não aconteceu, o terceiro caminho foi aplicar o questionário impresso direto em universidades, escolas, academias e outros ambientes de trabalho dos profissionais de educação física, além de eventos direcionados à área profissional. 
Esta amostra é caracterizada como uma amostra intencional não probabilística. A amostragem não probabilística é aquela em que a seleção dos elementos da população para compor a amostra depende ao menos em parte do julgamento do pesquisador ou do entrevistador no campo (MATTAR, 1996). Neste sentido, as amostragens não probabilísticas servem para sondagens sem propósitos inferenciais, ou seja, os resultados obtidos não podem ser estendidos para toda a população. A amostra não probabilística pode ser de quatro tipos: acidental (ou conveniência), intencional (ou de julgamento), quotas (ou proporcional) e desproporcional.

A amostra não probabilística intencional é quando o pesquisador usa o seu julgamento para selecionar os membros da população que irão compor a sua amostra, esta seleção é feita considerando que a amostra seja de interesse do pesquisador e poderá oferecer as contribuições solicitadas. Neste caso, os participantes da amostra são escolhidos por terem alguma característica que seja objeto de pesquisa (CHURCHILL, 1998; BRACARENSE, 2012). Foi escolhida uma amostra não probabilística intencional, pois este estudo não tem como objetivo generalizar os dados obtidos na amostra para a população e os participantes da amostra têm uma característica que é objeto de pesquisa (são da área de educação física).

Além disso, para estimar o tamanho da nossa amostra tivemos como referência Kline (2011), que diz que qualquer análise fatorial confirmatória precisa ter uma amostra de pelo menos 200 sujeitos ("rule of thumb"). Entretanto, é importante ressaltar que existem outras abordagens para estimar a amostra como colocar um número variável de sujeitos devido a certos critérios que relacionam o tamanho da amostra com o número de indicadores ou de parâmetros a serem estimados, como Hair et al. (1998), Bentler e Chou (1987) e Wolf et al. (2013).

A amostra final do estudo foi composta por 317 profissionais e estudantes de educação física, destes a maioria eram estudantes de educação física $(n=224,70,7 \%)$ e idade média dos participantes foi de 24 anos $(\mathrm{DP}=6,1)$. Também encontramos que a maioria dos participantes eram homens $(n=201,63,4 \%)$ e solteiros $($ as $)(n=287,90,5 \%)$.

\subsection{Instrumento}

O instrumento utilizado para a investigação foi um questionário composto por quatro partes. Na primeira parte do questionário foi utilizada a Escala de Educação e Valores Olímpicos (EEVO-36) (RABELO et al., 2016) a fim de mensurar a percepção dos valores pela população investigada. Na segunda parte do questionário, foi utilizado a escala semântica adaptada de Shank e Beasley (1998) a fim de mensurar o envolvimento atitudinal. Na terceira parte foi utilizado questionário sobre hábitos midiáticos, também adaptada de Shank e Beasley (1998), a fim de mensurar o envolvimento comportamental. E na última parte do questionário, foi 
utilizado um grupo de questões sociodemográficas com o intuito de caracterizar a amostra. As três primeiras partes do questionário serão tratadas de modo mais aprofundado nas subseções seguintes.

\subsubsection{Escala de Educação e Valores Olímpicos (EEVO-36)}

A Escala de Educação e Valores Olímpicos (EEVO) foi desenvolvida por Rabelo, Peixoto, Nakano e Rubio (2016), com o objetivo de mensurar aspectos da percepção de alunos e professores da rede pública de educação municipal da cidade de São Paulo a respeito da prática esportiva e, sobretudo, dos valores humanos inerentes ao contexto olímpico (RABELO et al., 2016). Os primeiros estudos, como desenvolvimento dos itens e avaliação de evidência de validade de conteúdo, foram conduzidos no laboratório de pesquisa Observatório de Psicologia do Esporte da Escola de Educação Física e Esportes da Universidade de São Paulo (EEFE-USP) (RABELO et al., 2016).

Quanto ao processo de construção do instrumento, os autores desenvolveram um conjunto de 104 itens por meio da operacionalização dos valores olímpicos tratados por Rubio (2009). Estes itens foram submetidos a avaliação de juízes para verificação dos construtos, bem como para verificação da interpretabilidade junto a população alvo (CASTRO; RABELO; RUBIO, 2013). Os resultados indicaram a pertinência de 70 itens, os quais foram retidos e submetidos a estudos posteriores, como o realizado por Rabelo, Rubio e Ambiel (2013). Para verificar a validade de estrutura interna os pesquisadores fizeram uma validação cruzada por meio da Análise Fatorial Exploratória e Análise Fatorial Confirmatória Categórica (RABELO et al., 2016). Está validação mostrou uma estrutura interna composta por três fatores que os autores chamaram de trabalho em equipe, busca por excelência e autocontrole. A partir de tais resultados, os autores sugeriram uma versão composta por 36 itens, aqueles mais informativos, os quais eram divididos igualmente entre os fatores (RABELO et al., 2016).

No presente estudo, a Escala de Educação e Valores Olímpicos (EEVO-36) de Rabelo et al. (2016) foi utilizada e teve a seguinte pergunta para responder os itens: "Avalie o quão bem ou mal as sentenças abaixo te descrevem profissionalmente". A partir disso, o indivíduo deveria responder os itens da EEVO-36 em um sistema de resposta em escala do tipo Likert de cinco pontos, variando de (1) muito mal a (5) muito bem. Os 36 itens foram dispostos de forma aleatória a fim de evitar respostas tendenciosas (veja Apêndice A, parte 1).

\subsubsection{Escala de Envolvimento e Questionário Sobre Hábitos Midiáticos}

Shank e Beasley (1998) tiveram como objetivo em seu estudo desenvolver uma escala para capturar o constructo envolvimento esportivo. A partir deste estudo, duas dimensões do 
envolvimento esportivo foram encontradas: uma dimensão cognitiva e uma afetiva. Ambos fatores foram relacionados a assistir esportes na televisão, ler sobre esportes em revistas e jornais, acompanhar eventos esportivos e participar de esportes. Isto é, de acordo com o proposto por Shank e Beasley (1998), o envolvimento de uma pessoa com o esporte ou com um evento esportivo está diretamente ligado a quanto esta pessoa procurar assistir, ler sobre ou praticar esportes. O questionário do estudo de Shank e Beasley (1998) foi administrado à uma amostra de consumidores nos Estados Unidos. Os itens deste questionário de envolvimento esportivo foram gerados a partir de uma revisão dos estudos sobre envolvimento. Para além do encontrado na literatura, os autores também utilizaram entrevistas com consumidores, que foram conduzidas com a finalidade de ganhar melhor entendimento a respeito do constructo envolvimento esportivo e apoiar o desenvolvimento do questionário de envolvimento esportivo. O questionário usado para coletar as informações do artigo do Shank e Beasley (1998) consiste em quatro seções. Na primeira, os respondentes completaram o questionário de envolvimento esportivo. Na segunda, os respondentes foram perguntados sobre os hábitos midiáticos deles (por exemplo, assistir televisão) relacionados ao esporte. A terceira seção do instrumento continha questões sobre a participação esportiva dos respondentes. $\mathrm{Na}$ última seção do instrumento, foram obtidas informações demográficas dos respondentes. A utilização destas quatro seções visou investigar o envolvimento esportivo em suas múltiplas facetas. No presente estudo foram utilizadas a primeira e a segunda seção deste questionário desenvolvido por Shank e Beasley (1998), de forma adaptada para a população e contexto do estudo. A primeira seção do questionário de Shank e Beasley (1998) foi adaptada e utilizada a fim de mensurar o envolvimento atitudinal nos respondentes em relação aos JO. Esta é uma escala de diferencial semântico que varia de "1" a "7" tendo palavras de significados opostos dispostas nas extremidades da escala, que deveriam representar a percepção dos respondentes com relação aos JO Rio 2016. Por exemplo, no primeiro item foram confrontados os termos "emocionantes" e "chatos", se o respondente achasse que os JO do Rio foram totalmente "emocionantes", ele circularia o "7" na primeira linha, se o respondente achasse que os Jogos foram totalmente "chatos", ele circularia o número "1" na primeira linha. Os demais números na escala semântica permitiam ao respondente "graduar" quanto chatos ou emocionantes foram os Jogos para ele/a. Esta seção foi desenhada para medir envolvimento atitudinal das pessoas com o evento (veja Apêndice A, parte 2). A seção era iniciada com a seguinte pergunta: “Avalie os sentimentos que você tem com relação aos Jogos Olímpicos de 2016 do Rio de Janeiro (por favor, circule)". A segunda seção do questionário de Shank e Beasley (1998) foi adaptada e utilizada a fim de mensurar o envolvimento comportamental dos respondentes em relação aos JO. Esta seção do 
questionário está relacionada aos hábitos midiáticos do respondente frente aos JO (veja Apêndice A, parte 3).

\subsection{Análise dos dados}

Num momento inicial os dados foram analisados através de estatística descritiva, sendo utilizadas média e desvio padrão para descrever a amostra. Após a análise descritiva dos dados, foi iniciada a rodagem dos testes $t$ para saber se havia diferença entre dois grupos: os profissionais de educação física e os estudantes de educação física. Para isso, foram feitos três testes $t$, um para cada fator dos valores humanos (trabalho em equipe, excelência e autocontrole). Foi utilizada a média geral dos 12 itens que representavam cada fator para criar um valor único para cada indivíduo. Também foi feito um quarto teste $t$ para o envolvimento atitudinal comparando profissionais e estudantes. Para esta análise, foi utilizada a média dos oito itens que representavam esse constructo. O SPSS 20 foi utilizado para conduzir as análises descritivas e os testes $t$.

Depois as escalas usadas no estudo - a escala de valores (RABELO et al., 2016) e a escala de envolvimento atitudinal (SHANK; BEASLEY, 1998) - foram analisadas através de análise fatorial confirmatória (THOMAS; NELSON; SILVERMAN, 2012). A opção pela análise fatorial confirmatória ao invés da exploratória se deve ao fato de estas escalas já terem sido testadas antes e estarem disponíveis na literatura.

$\mathrm{Na}$ análise fatorial confirmatória foram consideradas como variáveis latentes os três fatores relacionados aos valores humanos, sendo eles o trabalho em equipe, a excelência e o autocontrole, e foram consideradas como variáveis observadas 12 itens para cada uma das variáveis latentes dos valores humanos. Também foi considerada como variável latente o constructo "envolvimento atitudinal", representado por oito itens de uma escala semântica. O "envolvimento comportamental" foi representado por três variáveis observadas. O software Mplus 7.11 foi usado para conduzir a análise fatorial confirmatória.

\subsection{Análise de regressão múltipla}

Para atender ao objetivo da pesquisa que foi descrever a relação entre envolvimento com os JO Rio 2016 e a percepção que estudantes e profissionais de educação física têm de valores humanos, foram feitas três análises - uma análise para cada valor humano. Isto é, cada valor humano foi considerado como variável dependente (VD) em uma análise de regressão. Nestas análises de regressão, tem-se quatro variáveis independentes (VI), representando o envolvimento com os Jogos Rio 2016: (1) envolvimento atitudinal (representado por oito itens), (2) envolvimento comportamental ao assistir os Jogos ao vivo, (3) envolvimento 
comportamental ao assistir os Jogos pela TV e (4) envolvimento comportamental ao assistir pela internet. Além disto, foram usados os outros dois valores humanos como variáveis independentes, pois a percepção de um valor poderia explicar um outro valor. Variáveis demográficas (idade, sexo e estado civil) foram usadas como variáveis controle. O SPSS 20 foi utilizado para rodar as três análises de regressão múltipla, com entrada simultânea das VIs. A descrição, tipo e nível de mensuração das variáveis da análise de regressão múltipla estão descritos na Tabela 1.

Os três modelos foram representados pelas seguintes equações

$$
\begin{aligned}
& \mathrm{Y}_{\mathrm{TEQ}}=\mathrm{b}_{0}+\mathrm{b}_{1} \mathrm{X}_{\mathrm{env} \_\mathrm{ati}}+\mathrm{b}_{2} \mathrm{X}_{\mathrm{ao} \_ \text {vivo }}+\mathrm{b}_{3} \mathrm{X}_{\mathrm{tv}}+\mathrm{b}_{4} \mathrm{X}_{\text {internet }}+\mathrm{b}_{5} \mathrm{X}_{\mathrm{exc}}+ \\
& \mathrm{b}_{6} \mathrm{X}_{\mathrm{aut}}+\mathrm{b}_{7} \text { idade }+\mathrm{b}_{8} \text { Sexo }+\mathrm{b}_{9} \text { civil } \\
& \mathrm{Y}_{\mathrm{EXC}}=\mathrm{b}_{0}+\mathrm{b}_{1} \mathrm{X}_{\text {env_ati }}+\mathrm{b}_{2} \mathrm{X}_{\mathrm{ao} \_ \text {vivo }}+\mathrm{b}_{3} \mathrm{X}_{\mathrm{tv}}+\mathrm{b}_{4} \mathrm{X}_{\text {internet }}+\mathrm{b}_{5} \mathrm{X}_{\mathrm{teq}}+ \\
& \mathrm{b}_{6} \mathrm{X}_{\mathrm{aut}}+\mathrm{b}_{5} \text { idade }+\mathrm{b}_{6} \text { SeXo }+\mathrm{b}_{7} \text { civil } \\
& \mathrm{Y}_{\mathrm{AUT}}=\mathrm{b}_{0}+\mathrm{b}_{1} \mathrm{X}_{\text {env_ati }}+\mathrm{b}_{2} \mathrm{X}_{\mathrm{ao} \_ \text {vivo }}+\mathrm{b}_{3} \mathrm{X}_{\mathrm{tv}}+\mathrm{b}_{4} \mathrm{X}_{\text {internet }}+\mathrm{b}_{5} \mathrm{X}_{\mathrm{teq}}+ \\
& \mathrm{b}_{6} \mathrm{X}_{\mathrm{exc}}+\mathrm{b}_{5} \text { idade }+\mathrm{b}_{6} \text { Sexo }+\mathrm{b}_{7} \text { civil }
\end{aligned}
$$

\begin{tabular}{|c|c|c|c|}
\hline $\begin{array}{l}\text { Variá- } \\
\text { vel }\end{array}$ & Descrição & Tipo de variável & $\begin{array}{l}\text { Nível de men- } \\
\text { suração }\end{array}$ \\
\hline $\mathrm{Y}_{\mathrm{TEQ}}$ & $\begin{array}{l}\text { Trabalho em equipe, um dos fatores que } \\
\text { representam os valores humanos; }\end{array}$ & Variável dependente & Intervalar \\
\hline $\mathrm{Y}_{\mathrm{EXC}}$ & $\begin{array}{l}\text { Excelência, um dos fatores que repre- } \\
\text { sentam os valores humanos; }\end{array}$ & Variável dependente & Intervalar \\
\hline $\mathrm{Y}_{\mathrm{AUT}}$ & $\begin{array}{l}\text { Autocontrole, um dos fatores que repre- } \\
\text { sentam os valores humanos; }\end{array}$ & Variável dependente & Intervalar \\
\hline$X_{\text {env_ati }}$ & $\begin{array}{l}\text { Envolvimento atitudinal, representado } \\
\text { por oito itens medidos numa escala de } \\
\text { diferencial semântico }\end{array}$ & $\begin{array}{l}\text { Variável } \\
\text { dente }\end{array}$ & Intervalar \\
\hline $\mathrm{X}_{\text {ao_vivo }}$ & $\begin{array}{l}\text { Envolvimento comportamental - Fato } \\
\text { de ter ido ou não assistir eventos ao vivo } \\
\text { na Rio } 2016\end{array}$ & $\begin{array}{l}\text { Variável } \\
\text { dente }\end{array}$ & $\begin{array}{l}\text { Nominal (dico- } \\
\text { tômica: } 0 \text { - não } \\
\text { foi; } 1 \text { - foi) }\end{array}$ \\
\hline $\mathrm{X}_{\mathrm{tv}}$ & $\begin{array}{l}\text { Envolvimento comportamental - Quan- } \\
\text { tidade de horas que assistiu na TV even- } \\
\text { tos relaciona aos Jogos Rio 2016, du- } \\
\text { rante o evento }\end{array}$ & $\begin{array}{l}\text { Variável } \\
\text { dente }\end{array}$ & Intervalar \\
\hline $\mathrm{X}_{\text {internet }}$ & $\begin{array}{l}\text { Envolvimento comportamental - Quan- } \\
\text { tidade de horas que usou a internet para } \\
\text { assistir, ler, compartilhar notícias sobre } \\
\text { os Jogos Rio 2016, durante o evento }\end{array}$ & $\begin{array}{l}\text { Variável } \\
\text { dente }\end{array}$ & Intervalar \\
\hline
\end{tabular}

Tabela 1 - Descrição, tipo e nível de mensuração das variáveis da análise de regressão múltipla 


\begin{tabular}{|c|c|c|c|}
\hline$X_{\text {exc }}$ & $\begin{array}{l}\text { Excelência, um dos fatores que repre- } \\
\text { sentam os valores humanos; }\end{array}$ & $\begin{array}{l}\text { Variável } \\
\text { pendente }\end{array}$ & Intervalar \\
\hline $\mathrm{X}_{\text {aut }}$ & $\begin{array}{l}\text { Autocontrole, um dos fatores que repre- } \\
\text { sentam os valores humanos; }\end{array}$ & $\begin{array}{l}\text { Variável } \\
\text { pendente }\end{array}$ & Intervalar \\
\hline$X_{\text {teq }}$ & $\begin{array}{l}\text { Trabalho em equipe, um dos fatores que } \\
\text { representam os valores humanos; }\end{array}$ & $\begin{array}{l}\text { Variável } \\
\text { pendente }\end{array}$ & Intervalar \\
\hline Idade & Idade do participante em anos & Variável controle & Intervalar \\
\hline Sexo & Sexo informado pelo participante & Variável controle & $\begin{array}{l}\text { Nominal (dico- } \\
\text { tômica: } 0 \\
\text { masculino; } 1 \text { - } \\
\text { feminino) }\end{array}$ \\
\hline $\begin{array}{l}\text { Estado } \\
\text { Civil }\end{array}$ & $\begin{array}{l}\text { Estado civil do participante, indicando } \\
\text { se era casado ou não (solteiro, separado, } \\
\text { divorciado) }\end{array}$ & Variável controle & $\begin{array}{l}\text { Nominal (dico- } \\
\text { tômica: } 0 \text { - não } \\
\text { casado; } 1 \text { - ca- } \\
\text { sado) }\end{array}$ \\
\hline
\end{tabular}

Os pressupostos para a análise de regressão múltipla foram testados. A relação entre os Xs e o Y de cada equação se mostrou linear, os valores dos resíduos são independentes e mostraram uma distribuição normal e a variância dos resíduos foi constante para todas as variáveis. 


\section{RESULTADOS}

Após análise descritiva das características sociodemográficas foi feita uma análise descritiva das variáveis do estudo. Nessa análise foi verificada a frequência e a média das variáveis que compunham o envolvimento comportamental: (1) assistir os JO ao vivo, (2) assistir os JO pela TV e (3) assistir/ler/comentar os JO pela internet. Para a primeira variável foi utilizada uma análise de frequência em que se verificou que $90,8 \%$ dos respondentes relataram não terem ido assistir aos $\mathrm{JO}$ ao vivo. Já para a variável envolvimento comportamental assistir os JO pela TV, os respondentes relataram ter assistido uma média de 3 horas por dia $(D P=2,58)$. E para a última variável comportamental, foi constatado que os respondentes usaram uma média de 2 horas por dia $(D P=2,06)$ assistindo/lendo/comentado aos JO pela internet.

Foi encontrado nos testes $t$ que profissionais não diferiram de estudantes em dois dos três fatores de valores humanos - trabalho em equipe $(t=-1,115 ; d f=311 ; p=0,266) \mathrm{e}$ excelência $(t=-1,028 ; d f=311 ; p=0,305)$, além de não diferirem no envolvimento atitudinal também $(t=1,392 ; d f=311 ; p=0,165)$ tendo diferença apenas no autocontrole $(t=3,366 ; d f$ $=311 ; p=0,001)$, onde os estudantes apresentaram valores mais altos, indicando que estes têm mais dificuldades de expressar autocontrole do que profissionais. Desta forma, como os dois grupos não diferiram na maioria das variáveis, foram considerados um único grupo nas análises subsequentes.

\subsection{Análise fatorial confirmatória (AFC)}

Foi utilizada a AFC como ponto de partida principalmente porque foi utilizada uma escala já testada em sua validade e fidedignidade, a escala EEVO-36 de Rabelo et al. (2016). Foi testada a escala EEVO-36 de Rabelo et al. (2016) na amostra com profissionais e estudantes de EFE, todos adultos. A AFC mostrou que o modelo não se adequou aos dados desta amostra $(R M S E A=0,064 ; C F I=0,720 ; T L I=0,721)$. Hair et al. (2009) indicam que para um modelo se adequar bem aos dados ele deve ter os seguintes índices: $R M S E A \leq 0,05, C F I$ e $T L I \geq 0,950$, sendo que para se adequar razoavelmente bem deve ter pelo menos os seguintes índices: $R M S E A \leq 0,08, C F I$ e $T L I \geq 0,900)$.

$\mathrm{Na}$ AFC para a variável envolvimento atitudinal, o modelo se adequou razoavelmente bem aos dados a $(R M S E A=0,080 ; C F I=0,967 ; T L I=0,939)$, não havendo necessidade de modificações nesta escala.

\subsection{Análise fatorial exploratória (AFE)}

Como o modelo original da EEVO-36 não se adequou aos dados, foi necessário se dar 
um passo atrás e conduzir uma AFE. O software Mplus 7.11 foi utilizado para rodar a AFE. Nesta AFE, para manter um item associado a um fator foi considerado uma carga fatorial de pelo menos 0,32, conforme sugerido por Costello e Osborne (2005) e Tabachnick e Fidell (2001). AFE mostrou um resultado com três fatores como uma boa possibilidade (eigenvalue = 2.042 e análise do gráfico de Scree). Alguns itens da escala original não carregaram suficientemente alto em nenhum dos três fatores. Assim, optou-se por eliminar estes itens de análises futuras. A Tabela 2 abaixo mostra que sete itens de cada um dos fatores originais carregaram em um fator, sem carregamento cruzado. Desta forma, manteve-se os nomes dos fatores propostos por Rabelo et al. (2016), mas foi reduzida a quantidade de itens representando cada fator de 12 para sete.

\begin{tabular}{|c|c|c|c|c|c|}
\hline \multirow[b]{2}{*}{ Fator } & \multirow[b]{2}{*}{ Item } & & \multicolumn{3}{|c|}{ Carga Fatorial } \\
\hline & & & $\mathbf{I}$ & II & III \\
\hline \multirow{7}{*}{ Trabalho em equipe } & Empolgo-me em propor atividades que envolvam superação & TEQ_2 & $\mathbf{0 , 3 4 0}$ & 0,189 & 0,016 \\
\hline & O sucesso dos meus alunos/atletas é positivo para mim. & TEQ_3 & $\mathbf{0 , 3 4 1}$ & 0,288 & 0,147 \\
\hline & Procuro fazer com que os meus alunos/atletas se sintam bem. & TEQ_8 & 0,496 & 0,233 & 0,184 \\
\hline & Preocupo-me com meus alunos/atletas. & TEQ_9 & 0,626 & 0,137 & 0,165 \\
\hline & $\begin{array}{l}\text { Nos treinos/aulas procuro achar uma melhor forma de realizar } \\
\text { a tarefa para melhorar o desempenho dos meus alunos/atletas. }\end{array}$ & TEQ_10 & $\mathbf{0 , 5 4 1}$ & 0,335 & 0,122 \\
\hline & $\begin{array}{l}\text { Procuro apoiar meus alunos/atletas quando observo-os tendo } \\
\text { alguma dificuldade. }\end{array}$ & TEQ_11 & 0,651 & 0,213 & 0,137 \\
\hline & Respeito os sentimentos das pessoas. & TEQ_12 & 0,420 & 0,288 & 0,128 \\
\hline \multirow{7}{*}{ Excelência } & $\begin{array}{l}\text { Não tenho dificuldade durante a aula/treino, pois não me } \\
\text { distraio com outras coisas. }\end{array}$ & EXC_3 & 0,059 & 0,424 & 0,072 \\
\hline & Aulas/treinos difíceis me motivam. & EXC_5 & 0,278 & $\mathbf{0 , 4 7 2}$ & $-0,041$ \\
\hline & Sou cuidadoso com regras e regulamentos. & EXC_6 & 0,162 & 0,404 & 0,1 \\
\hline & Tenho muita disposição para tarefas difíceis. & EXC_7 & 0,172 & 0,681 & $-0,013$ \\
\hline & $\begin{array}{l}\text { Não tenho dificuldade para me adaptar as atividades que } \\
\text { envolvam regras e regulamentos fixos. }\end{array}$ & EXC_8 & 0,175 & $\mathbf{0 , 4 3 7}$ & 0,112 \\
\hline & Nunca pensei em desistir de dar aula/treino. & EXC_10 & 0,089 & $\mathbf{0 , 4 6 0}$ & $-0,032$ \\
\hline & Fico motivado com frequência. & EXC_12 & 0,190 & $\mathbf{0 , 5 6 9}$ & 0,054 \\
\hline \multirow{7}{*}{ Auto-controle } & Com frequência, sinto vontade de agredir algumas pessoas. & AUT_3 & 0,089 & $-0,223$ & $-0,605$ \\
\hline & Frequentemente faço ameaças. & AUT_5 & $-0,072$ & $-0,081$ & $-0,614$ \\
\hline & Frequentemente aumento o tom de voz para intimidar. & AUT_6 & $-0,042$ & 0,047 & $-0,566$ \\
\hline & Eu me divirto em apontar os erros de outros profissionais. & AUT_7 & 0,001 & $-0,151$ & $-\mathbf{0 , 5 5 8}$ \\
\hline & $\begin{array}{l}\text { Quando estou com raiva, pode acontecer que eu não cumpra } \\
\text { regras. }\end{array}$ & AUT_8 & $-0,108$ & $-0,127$ & $-0,640$ \\
\hline & $\begin{array}{l}\text { Se alguma pessoa me enganar, deverá receber na mesma } \\
\text { moeda. }\end{array}$ & AUT_10 & $-0,106$ & $-0,015$ & $-0,549$ \\
\hline & $\begin{array}{l}\text { Se eu precisar descumprir alguma regra para ganhar, eu farei } \\
\text { isso. }\end{array}$ & AUT_12 & $-0,237$ & 0,122 & $-0,579$ \\
\hline
\end{tabular}

\subsection{Alfa de Cronbach}

Os resultados do índice alfa de Cronbrach estão na Tabela 3, junto com a média $(M)$ e o 
desvio padrão $(D P)$ dos fatores principais da pesquisa. Os resultados mostram que todas as varáveis tiveram alfa acima de 0,700, o que é considerado por Nunnaly e Beirnstein (1994) uma medida de consistência interna dos itens e um indicativo de fidedignidade das escalas. Os valores de alfa dão suporte à opção de se usar a média das respostas dos itens como um indicador do fator que representam. Assim, para as análises subsequentes, foi usada a média dos sete itens que representam cada um dos fatores de valores humanos (trabalho em equipe, excelência e autocontrole) e a média dos oito itens que representaram o envolvimento atitudinal.

Tabela 3 - Média (M), desvio padrão (DP) e alfa de Cronbach das varáveis medidas por itens

\begin{tabular}{lccc}
\hline Fatores & $M$ & $D P$ & Alfa \\
\hline Trabalho em Equipe & 4,67 & 0,38 & 0,750 \\
Excelência & 3,98 & 0,59 & 0,724 \\
Autocontrole & 1,77 & 0,68 & 0,787 \\
Envolvimento atitudinal & 5,48 & 1,25 & 0,922 \\
\hline
\end{tabular}

\subsection{Análise de regressão múltipla}

Os resultados das análises de regressão múltipla são apresentados na Tabela 4 abaixo.

A Tabela 4 produziu as equações I $\left(\mathrm{VD}=\right.$ trabalho em equipe $\left.-\mathrm{Y}_{\mathrm{TEQ}}\right)$, II $(\mathrm{VD}=$ excelência $\left.-\mathrm{Y}_{\mathrm{EXC}}\right)$ e III (VD = autocontrole $\left.-\mathrm{Y}_{\mathrm{AUT}}\right)$ abaixo:

$$
\begin{aligned}
& \text { (I) } \mathrm{Y}_{\mathrm{TEQ}}=3,479+0,065 \mathrm{X}_{\text {env_ati }}-0,021 \mathrm{X}_{\mathrm{ao} \_ \text {vivo }}-0,007 \mathrm{X}_{\mathrm{tv}}+0,003 \mathrm{X}_{\text {internet }}+ \\
& 0,242 \mathrm{X}_{\text {excelencia }}-0,100 \mathrm{X}_{\text {autocontrole }}+0,002 \text { idade }+0,061 \text { sexo }-0,001 \text { civil } \\
& \text { (II) } \mathrm{Y}_{\mathrm{EXC}}=0,922-0,035 \mathrm{X}_{\text {env_ati }}-0,025 \mathrm{X}_{\mathrm{ao} \_ \text {vivo }}+0,019 \mathrm{X}_{\mathrm{tv}}-0,010 \mathrm{X}_{\text {internet }}+ \\
& 0,715 \mathrm{X}_{\text {trabalho em equipe }}-0,080 \mathrm{X}_{\text {autocontrole }}+0,004 \text { idade }-0,172 \text { sexo }-0,099 \text { civil }
\end{aligned}
$$

(III) $\quad \mathrm{Y}_{\mathrm{AUT}}=3,457+0,073 \mathrm{X}_{\text {env_ati }}-0,082 \mathrm{X}_{\text {ao_vivo }}-0,025 \mathrm{X}_{\mathrm{tv}}+0,040 \mathrm{X}_{\text {internet }}-$ $0,369 X_{\text {trabalho em equipe }}-0,099 X_{\text {excelência }}+0,001$ idade $-0,221$ sexo $-0,138$ civil 
Tabela 4 - Análise de regressão múltipla

\begin{tabular}{|c|c|c|c|c|c|}
\hline Modelo & & $\mathrm{b}$ & Beta & $T$ & $P$ \\
\hline \multirow{11}{*}{ Trabalho em Equipe } & (Constante) & 3.479 & & 13.704 & $<.001$ \\
\hline & Assistiu jogos ao vivo & -.021 & -.019 & -.271 & .787 \\
\hline & Horas Jogos na TV & -.007 & -.045 & -.592 & .555 \\
\hline & Horas Jogos na internet & .003 & .016 & .211 & .833 \\
\hline & Envolvimento atitudinal & .065 & .209 & 2.911 & .004 \\
\hline & Idade & .002 & .032 & .367 & .714 \\
\hline & Sexo & .061 & .088 & 1.239 & .217 \\
\hline & Estado civil & -.001 & .000 & -.006 & .996 \\
\hline & Excelência & .242 & .404 & 5.783 & $<.001$ \\
\hline & Autocontrole & -.100 & -.177 & -2.480 & .014 \\
\hline & (Constante) & .922 & & 1.442 & .151 \\
\hline \multirow{8}{*}{ Excelência } & Assistiu jogos ao vivo & -.025 & -.013 & -.183 & .855 \\
\hline & Horas Jogos na TV & .019 & .075 & .956 & .341 \\
\hline & Horas Jogos na internet & -.010 & -.034 & -.440 & .660 \\
\hline & Envolvimento atitudinal & -.035 & -.066 & -.877 & .382 \\
\hline & Idade & .004 & .048 & .526 & .600 \\
\hline & Sexo & -.172 & -.147 & -2.037 & .043 \\
\hline & Estado civil & -.099 & -.049 & -.543 & .588 \\
\hline & Autocontrole & -.080 & -.084 & -1.128 & .261 \\
\hline \multirow{11}{*}{ Autocontrole } & Trabalho em equipe & .715 & .428 & 5.783 & $<.001$ \\
\hline & (Constante) & 3.457 & & 5.211 & $<.001$ \\
\hline & Assistiu jogos ao vivo & -.082 & -.041 & -.546 & .586 \\
\hline & Horas Jogos na TV & -.025 & -.095 & -1.157 & .249 \\
\hline & Horas Jogos na internet & .040 & .130 & 1.610 & .109 \\
\hline & Envolvimento atitudinal & .073 & .132 & 1.661 & .099 \\
\hline & Idade & .001 & .011 & .118 & .906 \\
\hline & Sexo & -.221 & -.179 & -2.362 & .019 \\
\hline & Estado civil & -.138 & -.064 & -.677 & .500 \\
\hline & Trabalho em equipe & -.369 & -.209 & -2.480 & .014 \\
\hline & Excelência & -.099 & -.094 & -1.128 & .261 \\
\hline
\end{tabular}

A equação I foi significante, sendo que a combinação das variáveis independentes e 
controle explicaram 22,2\% da variância da VD trabalho em equipe (Adj $R$-square $=0,222 ; F=$ $6,346 ; p<0,001)$. O envolvimento atitudinal $(b=0,065 ; t=2,911 ; p=0,004)$, a excelência $(b$ $=0,242 ; t=5,783 ; p<0,001$ e o autocontrole $(b=-0,100 ; t=-2,480 ; p=0,014)$ foram os preditores significantes do valor trabalho em equipe Ou seja, para cada unidade que se aumenta em envolvimento atitudinal e excelência espera-se um aumento de, respectivamente, 0,065 e 0,242 em trabalho em equipe mantendo-se os outros preditores constantes. Assim como, esperase que para cada unidade que se aumenta de autocontrole espera-se uma diminuição de 0,100 em trabalho em equipe mantendo-se os outros preditores constantes. Vale lembrar que a variável autocontrole tem polo negativo, ou seja, seus itens representam falta de autocontrole, desta forma, quanto maior os valores desta variável, menor é a percepção de ter autocontrole do respondente. Em suma, pode-se dizer que quanto mais as pessoas se viam como tendo autocontrole, mas elas se viam como alguém que acreditava em trabalho em equipe.

A equação II foi significante, sendo que a combinação das variáveis independentes e controle explicaram 17,6\% da variância da VD excelência (Adj $R$-square $=0,176 ; F=5,004 ; p$ $<0,001)$. O trabalho em equipe $(b=0,715 ; t=5,783 ; p<0,001)$ foi o único preditor significante para o valor excelência. Ou seja, para cada unidade que se aumenta em trabalho em equipe espera-se um aumento de 0,715 em excelência mantendo-se os outros preditores constantes.

A equação III também foi significante, sendo que a combinação das variáveis independentes e controle explicaram 8,5\% da variância da VD autocontrole (Adj R-square = $0,085 ; F=2,745 ; p=0,005)$. O trabalho em equipe $(b=-0,369 ; t=-2,480 ; p=0,014)$ foi o único preditor significante para o valor autocontrole. Ou seja, para cada unidade que se aumenta em trabalho em equipe espera-se uma diminuição de 0,369 em autocontrole mantendo-se os outros preditores constantes. Da mesma forma que explicado anteriormente, o autocontrole tem polo negativo, assim, quanto mais as pessoas se descrevem como pessoas que trabalham em equipe mais elas se veem como pessoas com autocontrole. 


\section{DISCUSSÃO}

Os resultados mostraram que os estudantes e profissionais de educação física não diferiram na maioria das variáveis, mostrando ter semelhança quanto aos valores trabalho em equipe e excelência e quanto ao envolvimento atitudinal. Além da similaridade quanto aos interesses profissionais que existem entre esses dois grupos, isso pode ter acontecido também por conta do caráter homogêneo da amostra, por exemplo, mais de $90 \%$ dos respondentes eram solteiros. Outra variável que pode indicar uma homogeneidade da amostra é a idade dos participantes do estudo que teve uma média de 24 anos, idade que muitos deles ou estavam na graduação ou acabaram de sair dela, o que indica que dos respondentes que se declarem profissionais de educação física muitos deles são recém-formados. Diante disso, estudantes e profissionais de educação física foram colocados em um mesmo grupo para descrever a relação entre a percepção que eles têm dos valores humanos e do envolvimento deles com os JO Rio 2016.

A primeira contribuição do presente estudo foi testar a adequabilidade da escala EEVO36 para uma amostra de profissionais e estudantes de educação física e esporte. O fato do modelo da EEVO-36 não ter se adequado bem aos dados da presente pesquisa pode encontrar uma explicação na diferença entre as amostras utilizadas. A amostra do presente estudo foi mais homogênea (apenas adultos, somente profissionais ou estudantes de Educação Física), enquanto que no estudo de Rabelo et al. (2016) foi usada uma amostra mais heterogênea, composta por pessoas cujas idades variavam entre 9 e 62 anos, sendo crianças, jovens, adultos e idosos, tanto alunos como professores de educação física. A AFE mostrou que uma versão mais parcimoniosa da escala se adequa melhor ao tipo de população do presente estudo. Além disso, os três fatores propostos por Rabelo et al. (2016) foram mantidos, entretanto, foram utilizados para cada fator somente sete dos 12 itens da escala de Rabelo et al. (2016).

A segunda contribuição do presente estudo foi testar a relação entre envolvimento com os JO e a percepção de valores humanos. Isto é importante para pontuar se os JO têm sido um instrumento importante para que o Movimento Olímpico promova os valores humanos (chamados de olímpicos). Os resultados do presente estudo (equação de regressão I) mostraram que o envolvimento atitudinal com os JO pode influenciar as percepções que profissionais e estudantes de educação física têm do valor humano trabalho em equipe. No entanto, o envolvimento não foi capaz de explicar as percepções que eles têm dos outros dois valores humanos (equações II e III). O envolvimento é um importante fator que tem potencial para afetar diferentes fatores além do valor trabalho em equipe, como a lealdade. McGehee, Yoon e Cardenas (2003) afirmam que quanto mais envolvido com o produto o consumidor do esporte 
está, mais provável é que este se torne leal às atividades relacionadas ao produto esportivo e resista à mudança de produto, quando comparado com um consumidor com baixo nível de envolvimento. Além de afetar constructos como a lealdade, o constructo envolvimento esportivo também tem se mostrado um preditor relativamente bom dos comportamentos relacionados ao esporte (SHANK; BEASLEY, 1998). Desta forma, é possível identificar uma característica marcante do envolvimento esportivo, a capacidade de afetar o consumidor do esporte em diferentes aspectos, seja em termos de valores, como visto no presente estudo, seja em termos de comportamentos e atitudes, como visto na literatura (MCGEHEE; YOON; CARDENAS, 2003; SHANK; BEASLEY, 1998). Além disso, o envolvimento com o esporte pode indicar uma melhora no autocontrole do indivíduo, por exemplo, indivíduos que praticam esporte dão mais importância a estarem com o corpo em plena forma e saudável e por isso são mais resistentes a consumir drogas (SANCHES, 2007).

Outra relação encontrada nos resultados foi que os valores afetam os próprios valores entre si. Na literatura também é encontrado que os valores podem se afetar positiva e negativamente entre si, como é possível ver no estudo de Gouveia, Martínez, Meira e Milfont (2001), que avaliaram em que medida determinados valores mantém relações de compatibilidades (afetam positivamente) e conflitos (afetam negativamente) entre si, segundo a teoria de Schwartz (1992). A teoria de Schwartz (1992) defende que os valores representam três exigências humanas universais, e a partir dessas três exigências foram derivados 10 tipos motivacionais de valores que interagem entre si formando uma estrutura circular contínua em que os tipos motivacionais de valores se relacionam de maneira positiva e negativa. Gouveia, Martínez, Meira e Milfont (2001) concluíram que a teoria de Schwartz (1992) é adequada, entretanto alguns conflitos entre os valores não se comprovaram devido à complexidade da dinâmica dos valores que não pode ser apreendida por meio dos modelos de equações estruturais utilizados (GOUVEIA; MARTÍNEZ; MEIRA; MILFONT, 2001).

Adicionalmente, com base nos resultados (equação de regressão II), o valor trabalho em equipe afetou positivamente o valor excelência. Isto pode acontecer porque o trabalho quando realizado com diferentes olhares e saberes tende a ser mais refletido e assertivo, atingindo níveis mais altos de excelência. No esporte é possível encontrar essa mesma relação na qual a produção de resultados positivos demanda trabalho em equipe e demanda uma ação para além da individualidade do atleta (Rabelo et al., 2016). Profissionais da área da administração esportiva do Brasil compartilham dessa mesma ideia ao considerar que a combinação entre talento e organização tende a levar à resultados expressivos, desde que o termo organização seja entendido como a sinergia entre trabalho em equipe, liderança e planejamento (BASTOS, 
2003), assim, o trabalho em equipe compõe o constructo organização que é um fator importante para se atingir o sucesso (BASTOS, 2003). Vale ressaltar que a utilização do trabalho em equipe para melhorar a excelência é uma ferramenta muito presente no meio esportivo, mas também está muito presente no mundo coorporativo com a finalidade de aumentar a produtividade nas organizações (BASTOS; MOCSÁNYI, 2005). Os resultados também apresentaram a relação oposta em que o valor excelência afeta positivamente o valor trabalho em equipe (equação I). Assim, quanto mais alto o nível de excelência profissional de uma pessoa mais ela percebe a importância do trabalho em equipe.

Também foi encontrado (equação de regressão II) que o valor trabalho em equipe afeta negativamente o valor autocontrole (lembrando que o constructo autocontrole tem polo negativo, ou seja, quanto mais baixo a pontuação maior a percepção de autocontrole). Nesse sentido, os resultados parecem indicar que quanto mais a pessoa trabalha em equipe mais ela desenvolve sua habilidade de ter autocontrole com relação às suas atividades profissionais. Além disto, os resultados indicaram que o valor autocontrole afeta o trabalho em equipe (equação I). Isto pode acontecer porque quanto mais controle a pessoa tem de si mesma, maior sua capacidade de desenvolver o trabalho em equipe sem se limitar a agir somente motivado para o que é melhor para si. Diante destes resultados, pode-se ver que o valor trabalho em equipe afeta e é afetado por valores de excelência e autocontrole, contudo, excelência e autocontrole não afetam um ao outro. Também foi visto que o trabalho em equipe é afetado pelo fator envolvimento atitudinal. Desta forma, o constructo trabalho em equipe se apresenta como o elo que conecta os demais constructos.

O fato da percepção dos valores dos estudantes e profissionais não terem sido afetados de maneira significativa pelo envolvimento comportamental com os $\mathrm{JO}$ e pelo envolvimento atitudinal (para os valores de excelência e autocontrole) pode ter uma explicação no período em que a pesquisa foi administrada. A coleta de dados foi realizada no primeiro semestre de 2017, entre seis meses e um ano após os JO Rio 2016. Logo, os dados foram coletados após os $\mathrm{JO}$, em um período em que o clima festivo dá lugar à exposição dos gastos públicos e das promessas não cumpridas de legados consistentes. Assim como foi percebido pelos residentes da Coréia do Sul no estudo Kim, Gursoy e Lee (2006), em que mostraram que a percepção de legado dos residentes em relação à Copa do Mundo de 2002 mudaram negativamente e drasticamente após o evento. Kim, Gursoy e Lee (2006) verificaram que se os residentes perceberem que os benefícios gerados são significantemente abaixo do esperado, o que pode gerar uma mudança de percepção dos residentes em relação ao custo/benefício do evento. Desta 
forma, pode-se considerar uma influência do período em que a pesquisa foi aplicada na relação entre valores humanos e envolvimento com os JO.

No entanto, não se pode descartar a possibilidade de que os JO não têm sido instrumentos eficientes para desenvolver os valores humanos pregados pelo Movimento Olímpico. Parece que os JO são hoje mais um evento que tem seu foco voltado para o marketing e retorno financeiro do que para promoção do esporte e de valores associados ao esporte. Proni (1998) já afirmava há 20 anos atrás que existia um esforço generalizado de tornar o espetáculo esportivo mais atraente para o espectador e mais rentável para os clubes e federações. Isso pode ser reflexo da formação de uma cultura de consumo na sociedade como um todo que acabou impulsionando a mercantilização do mundo esportivo (PRONI, 1998). De acordo com documento do Instituto de Pesquisa Econômica Aplicada (2008), desde 1972 haviam fortes indícios de que os fundamentos do Olimpismo não poderiam ser mantidos por muito mais tempo, principalmente com a existência da transmissão via satélite que fazia ficar cada vez mais difícil conter uma comercialização excessiva. Hoje, além da transmissão via satélite, temos a internet, um fator em potencial para aumentar a comercialização dos JO.

Assim como no presente estudo, Rocha e Fink (2017) também investigaram estudantes e profissionais relacionados à área do esporte como amostra (estudantes de pós-graduação em gestão esportiva). Nessa pesquisa os respondentes indicaram que a associação entre a marca Olímpica deveria trazer menos ganhos para o turismo brasileiro que o esperado. Apesar de ser necessário mais pesquisas que corroborem com essa ideia, é possível vislumbrar uma tendência a um olhar mais crítico por parte de profissionais e estudantes da área esportiva quando se trata dos JO. Como consequência, as percepções pouco otimistas quanto aos benefícios e legados dos JO em termos comerciais, encontradas no estudo de Rocha e Fink (2017), parecem se repetir no presente estudo com relação aos benefícios em termos de desenvolvimento de valores.

Frawley e Cush (2011) evidenciaram a importância de criar um ambiente favorável à captação dos legados para se aproveitar o máximo possível o que os ME têm para oferecer, isso seria feito principalmente através da promoção de estratégias de alavancagem ("leverage”) dos legados. Da mesma forma, Bretherton et al. (2016) relatam que os governantes não podem contar unicamente com o status ou com a "inspiração" dos JO para aumentar a participação esportiva da população e devem perseguir de maneira mais proativa a este legado. Assim como a participação esportiva, a promoção de valores por meio dos JO é um legado que precisa de um planejamento para que se atinja bons níveis de desenvolvimento e retenção e, além disso, se caracterize como um legado de caráter consistente e duradouro. Os legados não devem ser tratados como meros acasos (CHALIP, 2006), mas sim como oportunidades que podem ser ricas 
ou pobres em benefícios dependendo de como são conduzidas. Não puderam ser identificadas nem na literatura, nem na mídia iniciativas que se preocupassem em associar os JO Rio 2016 com valores humanos. Ao contrário, o deslocamento de pessoas e a maquiagem de favelas (THE GUARDIAN, 2015; NY TIMES, 2016) parecem transmitir a ideia oposta, além de passar uma imagem de desrespeito aos valores humanos. Além disso, nem mesmo os impactos econômicos tiveram uma repercussão positiva na mídia, sendo esperado um impacto econômico negativo a curto prazo e uma expectativa baixa de melhora a longo prazo (BBC, 2015). 


\section{CONCLUSÃO}

Os ME são ocasiões com tempo determinado e que atraem muitos visitantes, têm um grande apelo midiático, vêm com grandes custos e têm grande impacto na infraestrutura e na população (MÜLLER, 2015). Desde o início, os JO modernos tinham como objetivo promover a educação por meio do esporte (OLYMPISM AND THE OLYMPIC MOVEMENT, 2013), a fim de nortear não só a educação olímpica, mas também a realização dos JO como um todo. Desta forma, surgiram os princípios e os valores olímpicos, que são mencionados em praticamente todos os acontecimentos relacionados ao COI e aos JO até hoje (OLYMPIC CHARTER, 2015; RUBIO, 2009). Visto a importância dos valores olímpicos (humanos) que permeiam o contexto olímpicos, foi possível, a partir dos resultados desse estudo, elaborar um modelo teórico que relaciona os valores e o envolvimento atitudinal, onde o valor trabalho em equipe é o ponto central sendo primeiro afetado pelo envolvimento atitudinal e posteriormente afetando e sendo afetado pelos valores excelência e autocontrole. O modelo teórico que surgiu a partir da presente investigação está representado abaixo (Figura 1).

Figura 1 - Modelo da relação entre envolvimento e valores humanos

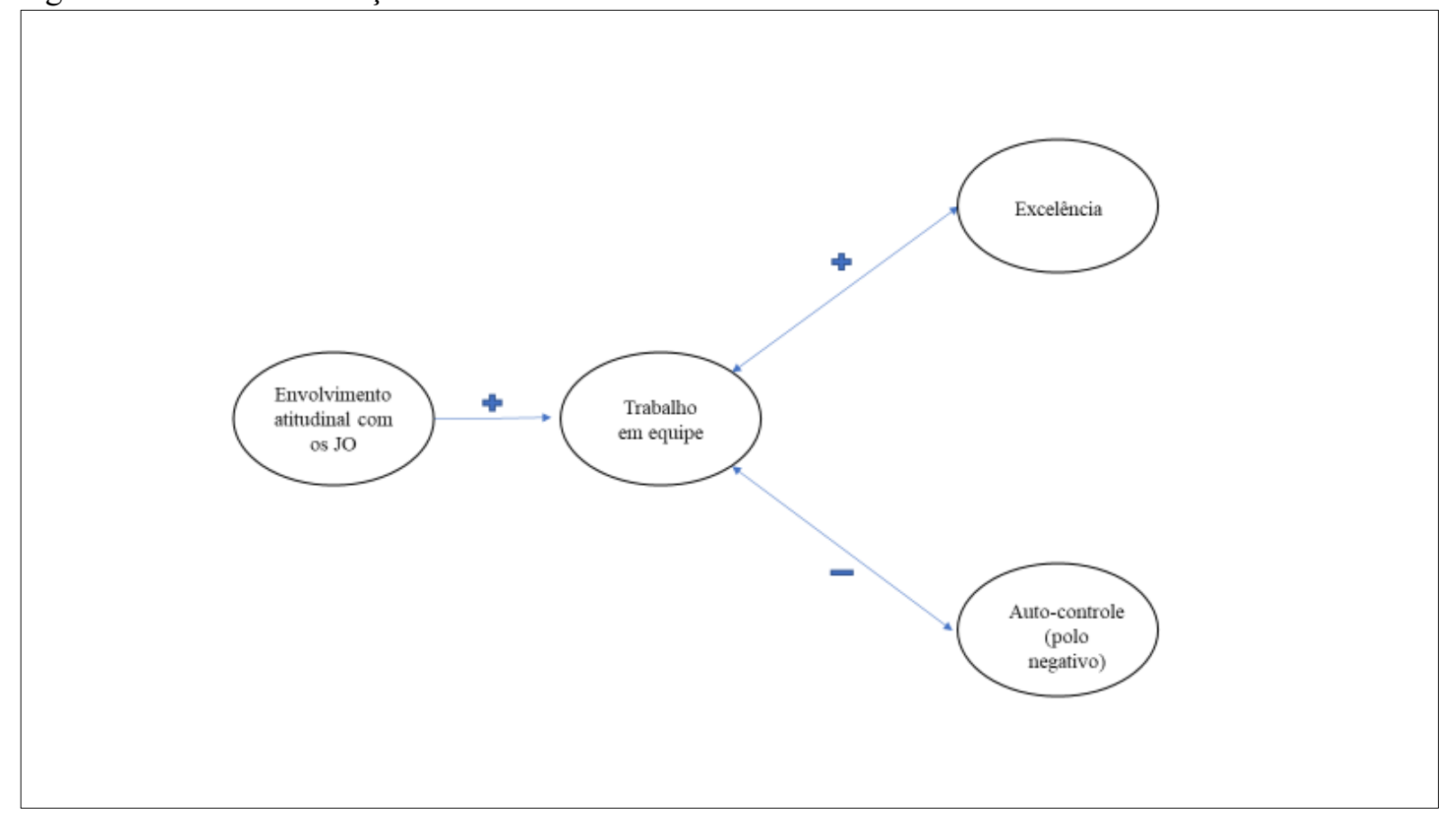

Além do modelo proposto diante das relações que se apresentaram de maneira significativa nos resultados, também vale ressaltar a relação que não se apresentou significativa e não entrou no modelo que foi a relação entre envolvimento comportamental e os valores humanos investigados nesse estudo. A falta de percepção dessa relação por parte dos estudantes 
e profissionais de educação física no pós-evento, pode ser consequência da falta de estratégias de alavancagem que tenham como objetivo promover os valores humanos que permeiam o contexto olímpico. Nesse sentido, uma estratégia de alavancagem do legado valores olímpicos voltados para estudantes e profissionais de educação física, que são disseminadores de valores através do esporte, pode ser uma alternativa para que os JO atinjam seu objetivo de disseminar os valores olímpicos principalmente entre as crianças e adolescentes. Uma alternativa para isto seria um programa efetivo de educação olímpica promovido pelos comitês organizadores dos JO, voltado principalmente para estudantes e profissionais da área de Educação Física e Esporte. Este programa deveria funcionar como uma estratégia de alavancagem interessante para os legados de valores olímpicos.

Estudos futuros podem explorar as relações propostas por este modelo e verificar, por exemplo, se iniciativas que exploram e valorizam o trabalho em equipe serviriam para melhorar a percepção das pessoas em termos da importância da excelência e do autocontrole nas atividades ligadas ao esporte. Estudos futuros podem também investigar outros valores humanos que podem ser afetados e afetar o envolvimento com os JO, como os valores de coragem, determinação, inspiração e igualdade citados na revisão de literatura; investigar os valores humanos e o envolvimento com os Jogos Paralímpicos; investigar os valores humanos e o envolvimento com os $\mathrm{JO}$ em outros grupos como os voluntários dos JO que vivenciam mais intensamente os JO; investigar os valores humanos e o envolvimento com os JO em outros períodos, como no pré-evento e durante o evento; e, investigar os valores humanos e o envolvimento com os JO na cidade sede.

Este estudo possui algumas limitações que precisam ser reconhecidas como: o uso de amostra intencional não probabilística, o que impedi que os resultados obtidos sejam estendidos para toda a população; o uso da amostra de uma cidade não sede (apesar de ser investigado os "spillover effects", o uso de uma amostra da cidade sede poderia retratar melhor os legados dos JO Rio 2016 relacionados aos valores humanos); o período em que a pesquisa foi aplicada (entre seis meses e um ano após os JO Rio 2016, pode ser considerado um período atrasado para se quantificar os legados pois estes podem ir se tornando menos expressivos com o passar do tempo); o uso de uma estratégia transversal, sendo que, talvez um estudo longitudinal pudesse mostrar a evolução na percepção de valores como decorrência de sediar os JO.

Apesar das limitações e possibilidades de estudos futuros, o presente estudo contribui para o desenvolvimento da literatura e prática da gestão de legados de ME. Ao investigar a relação entre envolvimento e percepções de valores olímpicos, os resultados mostraram que o envolvimento explicou pouca destas percepções, limitando-se ao valor trabalho em equipe. Isto 
pode ser resultado de duas causas distintas, mas interligadas. Primeira, uma falha no processo de gestão de legados, representado pela ausência de estratégias para alavancar a associação entre o evento em si os valores que este deveria transmitir. Segunda, uma real ausência de relação entre os JO e os valores olímpicos. Como no caso dos JO Rio 2016, a primeira causa foi um fato, isto é, não houve qualquer tentativa em massa de alavancar os valores olímpicos, não se pode afirmar se a segunda causa é um fato. Estudos futuros, em sedes onde a alavancagem dos valores olímpicos esteja efetivamente presente, poderão esclarecer se a relação entre os JO e os valores olímpicos está realmente diminuída. 


\section{REFERÊNCIAS}

ABRAÇA. Abraça-sustentabilidade. Disponível em:

$<$ https://www.rio2016.com/sustentabilidade/nossas-acoes/

>. Acesso em: 22 ago. 2016.

BASTOS, F. C. Administração esportiva: área de estudo, pesquisa e perspectivas no Brasil. Revista Motrivivência, 20-21, 296-306, 2003.

BASTOS, F. C.; MOCSÁNYI, V. Gestão de pessoas na administração esportiva: considerações sobre os principais processos. Revista Mackenzie de Educação Física e Esporte, 4, 4, 55-69, 2005.

BBC. Rio 2016: Olimpíada atrapalha ou ajuda o Brasil em recessão? Disponível em: <http://www.bbc.com/portuguese/noticias/2015/08/150803_olimpiada_ru>. Acesso em: 21 fev. 2018.

BEATON, A. A. et al. Sport involvement: a conceptual and empirical analysis. Sport Management Review, 14, 126-140, 2011.

BEATON, A. A.; FUNK, D. C.; ALEXANDRIS, K. Operationalizing a theory of participation in physically active leisure. Journal of Leisure Research, 41, 177-203, 2009.

BEESLEY, L.G.; CHALIP, L. Seeking (and not seeking) to leverage mega-sport events in nonhost destinations: The case of Shanghai and the Beijing Olympics. Journal of Sport \& Tourism, 16, 4, 323-344, 2011.

BENTLER, P. M.; CHOU, C.P. Practical issues in structural modeling. Sociological Methods \& Research, 16, 1, 78-117, 1987.

BINDER, D. L. Olympic values education: evolution of a pedagogy. Educational Review, 64, 3, 275-302, 2012.

BRACARENSE, P. A. Estatística aplicada às ciências sociais. Curitiba, IESDE Brasil S.A. 
2012.

ISBN:

$978-85-387-3269-3$

Disponível

em:

$<$ https://books.google.com.br/books?id=XM6WI1x_T_sC\&pg=PA87\&redir_esc=y\&hl=pt-

$\mathrm{BR} \# \mathrm{v}=$ onepage $\& \mathrm{q} \& \mathrm{f}=$ false $>$. Acesso em: 08 de nov. de 2017.

BRETHERTON, P.; PIGGIN, J.; BODET, G. Olympic sport and physical activity promotion: the rise and fall of the London 2012 pre-event mass participation "legacy". International Journal of Sport Policy, 8, 4, 609-624, 2016.

CADERNO LEGADOS SOCIAL. Disponível

$<$ http://www.esporte.gov.br/arquivos/rio2016/cadernoLegadosSocial.pdf $>$. Acesso em: 07 ago. 2016.

CARTA OLÍMPICA, 2011. Disponível em: $<$ http://www.pned.pt/media/1460/cartaolimpica.pdf>. Acesso em: 10 jul. 2017.

CASTRO, N.R., RABELO, I.S. \& RUBIO, K. Estudos de análise fatorial com a Escala de Educação e Valores Olímpicos (EEVO). Trabalho apresentado no VI Congresso Brasileiro de Avaliação Psicológica - IBAP, Maceió, AL, 2013.

CHALIP, L. Towards social leverage of sport events. Journal of Sport \& Tourism. 11, 2, 109$127,2006$.

CHALIP, L.; GREEN, B. C.; TAKS, M.; MISENER, L. Creating sport participation from sport events: making it happen. International Journal of Sport Policy and Politics, 9, 61-80, 2017.

CHURCHILL, G. Marketing research: methodological foundations. 2a ed. [S.I.]: The Dryden Press. 1998.

COI. Site do Comitê Olímpico Internacional. Disponível em: $<$ https://www.olympic.org/rio2016>. Acesso em: 21 fev. 2018.

COLLINS, A.; JONES, C.; MUNDAY, M. Assessing the environmental impacts of mega sporting events: two options? Tourism Management, 30, 828-837, 2009. 
COMMONWEALTH GAMES. 2017. Disponível em: http://sport.vic.gov.au/ourwork/events/commonwealth-games-legacy. Acesso em: 23 out. 2017.

COSTEllo, A. B.; OSBORNE, J. W. Best practices in exploratory factor analysis: Four recommendations for getting the most from your analysis. Practical Assessment, Research \& Evaluation, 10, 7, 1-9, 2005.

DECCIO, C.; BALOGLU, S. Nonhost community resident reactions to the 2002 Winter Olympics: the spillover impacts. Journal of Travel Research, 41, 1, 46-56, 2002.

DOSSIÊ RIO 2016. Dossiê de candidatura do Rio de Janeiro a sede dos Jogos Olímpicos e Paralímpicos de 2016, 2009. Disponível em: $<$ https://www.rio2016.com/sites/default/files/parceiros/dossie_de_candidatura_v1.pdf $>$. Acesso em: 07 ago. 2016.

FILO, K.; FUNK, D. C.; O’BRIEN, D. The meaning behind attachment: exploring camaraderie, cause, and competency at a charity sport event. Journal of Sport Management, 23, 361-387, 2009.

FOURIE, J.; GALlEGO, M. S. The impact of mega-events on tourist arrivals. Tourism Management, 32, 1364-1370, 2011.

FRAWLEY, S.; CUSH, A. Major sport events and participation legacy: the case of the 2003 Rugby World Cup. Managing Leisure. 16, 65-76, 2011.

FUNK, D. C.; LYNN, L.; RIDINGER, L.L.; ANITA, M.; MOORMAN, A. M. Exploring origins of involvement: understanding the relationship between consumer motives and involvement with professional sport teams, Leisure Sciences: An Interdisciplinary Journal, 26, 1, 35-61, 2004.

GAFFNEY, C. Between discourse and reality: the un-sustainability of mega-event planning. Sustainability, 5, 9, 3926-3940, 2013. 
GARDINER, S.; CHALIP, L. Leveraging a mega-event when not the host city: lessons from pre-olympic training [Gold Coast, Queensland]: Sustainable Tourism, 2006.

GIRGINOV, V.; HILLS, L. A sustainable sports legacy: creating a link between the London olympics and sports participation. The international journal of the history of sport, 25,14 , 2091-2116, 2008.

GOUVEIA, V. V.; MARTÍNEZ, E.; MEIRA, M.; MILFONT, T. L. A estrutura e o conteúdo universais dos valores humanos: análise fatorial confirmatória da tipologia de Schwartz. Estudos de Psicologia, 6, 2, 133-142, 2001.

GRATTON, C.; PREUSS, H. Maximizing olympic impacts by building up legacies. The International Journal of the History of Sport, 25, 14, 1922-1938, 2008.

GRIX, J. Sport politics and the olympics. Political Studies Review, 11, 15-25, 2013.

GRIFFITHS, M.; ARMOUR, K. Physical education and youth sport in England: conceptual and practical foundations for an olympic legacy? International Journal of Sport Policy and Politics, 5, 2, 213-227, 2013.

HAIR J. F.; BLACK W. C.; BABIN B. J.; ANDERSON R. E. Multivariate data analysis (7a ed.). Upper Saddle River, NJ: Prentice-Hall, 2009.

HAVITZ, M. E.; MANNELL, R. C. Enduring involvement, situational involvement, and flow in leisure and non-leisure activities. Journal of Leisure Research, 37, 2, 152-177, 2005.

HILLER, H. H.; WANNER, R. A. Public opinion in host olympic cities: the case of the 2010 Vancouver Winter Games. Sociology, 45, 883-906, 2011.

INSTITUTO DE PESQUISA ECONÔMICA APLICADA. Texto para discussão $n^{\circ} 1356$. Leitura econômica dos jogos olímpicos: financiamento, organização e resultados. Instituto de Pesquisa Econômica Aplicada, Rio de Janeiro, ago. 2008. Disponível em: $<$ http:/www.ipea.gov.br>. Acesso em: 21 fev. 2018. 
JIN, L.; ZHANG, J. J.; MA, X.; CONNAUGHTON, D. P. Residents' perceptions of environmental impacts of the 2008 Beijing Green Olympic Games. European Sport Management Quarterly, 11, 275-300, 2011.

KELLETT, P.; HEDE, A.; CHALIP L. Social policy for sport events: leveraging (relationships with) teams from other nations for community benefit. European Sport Management Quarterly, 8, 2, 101-121, 2008.

KIM, H. J.; GURSOY, D.; LEE, S.B. The impact of the 2002 World Cup on South Korea: comparisons of pre- and post-games. Tourism Management, 27, 86-96, 2006.

KIM, N. S.; CHALIP, L. Why travel to the FIFA World Cup? Effects of motives, background, interest, and constraints. Tourism management, 25, 6, 695-707, 2004.

KIM, S. S.; PETRICK, J. F. Residents' perceptions on the impacts of the FIFA 2002 World Cup: the case of Seoul as a host city. Tourism Management, 25, 25-38, 2005.

KLINE, R. B. Principles and practice of structural equation modeling, 3a Ed. [S.I.]: Methodology in the Social Sciences, 2011.

MATTAR, F. Pesquisa de marketing. [S.I.] Ed. Atlas. 1996.

MCGEHEE, N. G.; YOON, Y.; CARDENAS, D. Involvement and travel for recreational runners in North Carolina. Journal of Sport Management, 17, 305-324, 2003.

MISENER, L.; TAKS, M.; CHALIP, L.; GREEN, B. C. The elusive "trickle-down effect" of sport events: assumptions and missed opportunities. Managing Sport and Leisure, 20, 2, 135 $156,2015$.

MÜLLER, M. What makes an event a mega-event? Definitions and sizes. Leisure Studies, 34, 6, 627-642, 2015. 
MURPHY, N. M.; BAUMAN, A. Events-are they "bread and circuses" or public health interventions to increase population levels of physical activity? Journal of Physical Activity and Health, 4, 193-202, 2007.

NY TIMES. Officials Spent Big on Olympics, but Rio Natives Are Paying the Price, 2016. Disponível em: <https://www.nytimes.com/2016/08/15/sports/olympics/rio-favelas-brazilpoor-price-too-high.html>. Acesso em: 21 fev. 2018.

OLIVEIRA, C. P.; TAMAYO, A. Os valores como preditores de atitude e comportamentos: contribuições para um debate. Linhas Críticas, Brasília, 8, 14, 2002.

OLYMPIC CHARTER. 2015. Disponível em: < https://stillmed.olympic.org/Documents/olympic_charter_en.pdf $>$. Acesso em: 08 ago. 2016.

OLYMPIC LEGACY. Château de Vidy, 1007 Lausanne, Switzerland. Published by the International Olympic Committee. March 2013. Disponível em: <www.olympic.org>. Acesso em: 08 ago. 2016.

OLYMPISM AND THE OLYMPIC MOVEMENT, Editor: IOC, The Olympic Museum, Lausanne. Authors: The Olympic Museum Educational and Cultural Services. 2013. Disponível em:

https://stillmed.olympic.org/media/Document\%20Library/OlympicOrg/Documents/Document -Set-Teachers-The-Main-Olympic-Topics/Olympism-and-the-Olympic-Movement.pdf $>$. Acesso em: 11 fev. 2018.

OVEP. Olympic Values Education Programme. International Olympic Committee. Disponível em:

http://www.olympic.org/Documents/Reference_documents_Factsheets/Olympic_Values_Educ ation_Programme.pdf>. Acesso em: 12 out. 2015.

PROCHASKA, J. O.; DICLEMENTE, C. C.; NORCROSS, J. C. In search of how people change: applications to addictive behaviors. American Psychologist, 47, 1102-1114, 1992.

PRONI, M. W. Marketing e organização esportiva: elementos para uma história recente do 
esporte-espetáculo. Conexões: revista da faculdade de educação física da UNICAMP, Campinas, 1, 1, 82-94, 1998.

PREUSS, H. The conceptualisation and measurement of mega sport event legacies. Journal of Sport \& Tourism. 12, 207-227, 2007.

PREUSS, H.; SOLBERG, H. A. Attracting major sporting events: the role of local residents. European Sport Management Quarterely, 6, 4, 391-411, 2006.

RABELO, I. S.; PEIXOTO, E. M.; NAKANO, T. C.; RUBIO, K. Avaliação de valores olímpicos e humanitários na educação: proposta de um instrumento de medida. Revista Brasileira de Psicologia do Esporte, São Paulo, 6, 2, 2016.

RABELO, I.S.; RUBIO, K.; AMBIEL, R.M. Estudos iniciais de construção de uma escala de educação e valores olímpicos. Trabalho apresentado no VI Congresso Brasileiro de Avaliação Psicológica - IBAP, Maceió, AL, 2013.

RITCHIE, B. W.; SHIPWAY, R.; CLEEVE, B. Residents perceptions of mega-sporting events: a non-host city perspective of the 2012 London Olympic Games. Journal of Sport \& Tourism, 14, 2-3, 143-167, 2009.

ROCKEACH, M. The nature of human values. [New York]: Free, 1973.

ROCHA, C. M. Support of politicians for the 2016 Olympic Games in Rio de Janeiro. Leisure Studies. 2015. DOI: 10.1080/02614367.2015.1042508.

ROCHA, C. M.; FINK, J. S. Attitudes toward attending the 2016 Olympic Games and visiting Brazil after the games. Tourism Management Perspectives, 22, 17-26, 2017.

ROCHA, C. M.; BARBANTI, V. J.; CHELLADURAI, P. Support of local residents for the 2016 Olympic Games. Event Management, 21, 251-268, 2017.

ROCHE, M. Mega-events and modernity. [London]: Routledge, 2000. 
RUBIO, K. Esporte, educação e valores olímpicos. [São Paulo]: Casa do Psicólogo, 2009.

RUBIO, K. Psicologia, esporte e valores olímpicos. [São Paulo]: Casa do Psicólogo, 2012.

SANCHES, S. M. A prática esportiva como uma atividade potencialmente promotora de resiliência. Revista Brasileira do Esporte, 1, 1, 1-15, 2007.

SHANK, M. D.; BEASLEY, F. M. Fan or fanatic: ferining a measure of sport involvement. Journal of Sport Behavior, 21, 4, 435, 1998.

SCHWARTZ, S. H. Universals in the context and structure of values: theoretical advances and empirical tests in 20 countries. In M. Zanna (Org.), Advances in experimental social psychology, Orlando: Academic Press, 25, 1- 65, 1992.

TABACHNICK, B. G.; FIDELL, L. S. Using multivariate statistics (5th ed.). [Boston]: Pearson/Allyn \& Bacon, 2007.

THE GUARDIAN. Brazil officials evict families from homes ahead of 2016 Olympic Games, 2015. Disponível em: <https://www.theguardian.com/world/2015/oct/28/brazil-officials-evicting-families-2016-olympic-games>. Acesso em: 21 fev. 2018.

WATT, P. "It's not for us". Regeneration, the 2012 Olympics and the gentrification of East London. City, 17, 1, 99-118, 2013.

WEED, M. et al. The Olympic Games and raising sport participation: a systematic review of evidence and an interrogation of policy for a demonstration effect, European Sport Management Quarterly, 15, 2, 195-226, 2015.

WEIMAR, D.; ROCHA, C. M. Does Distance Matter? Geographical Distance and Domestic Support for Mega Sports Events. Journal of Sports Economics, 2017. Retirado de: http://journals.sagepub.com/doi/abs/10.1177/1527002517724505. 
WOlF, E. J.; HARRINGTON, K. M.; CLARK, S. L.; MiLlER, M. W. Sample size requirements for structural equation models: an evaluation of power, bias, and solution propriety. Educational Psychological Measurement, 76, 6, 913-934, 2013.

ZAICHKOWSKY, J. L. Measuring the involvement construct. Journal of Consumer Research, 12, 3, 341-352, 1985. 


\section{APÊNDICES}

Apêndice A

ESCALA - EDUCAÇÃO E VALORES OLÍMPICOS (EEVO-36) (RABELO et al., 2016)

\section{Instruções:}

Você está sendo convidado a responder um questionário sobre valores e envolvimento com os Jogos Olímpicos.

Não existem respostas certas ou erradas. É importante que as suas respostas sejam sinceras. Responda a todos os itens e, assinale apenas uma única resposta para cada afirmação.

O questionário é ANÔNIMO, assim ninguém ficará sabendo as suas respostas.

O questionário demora em média 7 minutos para ser respondido.

Esta pesquisa foi aprovada pelo comitê de ética da Escola de Educação Física e Esporte de Ribeirão Preto. Se tiver alguma dúvida, por favor, fique a vontade para entrar em contato comigo, que sou o responsável pela pesquisa.

Agradeço antecipadamente a sua participação.

Prof. Otávio Gratão - (16) 3315-0348 - otavio.gratao@usp.br

Não existem respostas certas ou erradas. É importante que as suas respostas sejam sinceras. Responda a todas as sentenças e, assinale apenas uma única resposta para cada afirmação. 


\section{PARTE 1 - PERCEPÇÃO DOS VALORES}

A seguir serão apresentadas sentenças que descrevem sentimentos, opiniões e atitudes. Por favor, leia atentamente cada uma das sentenças e responda o quanto elas dizem a seu respeito.

Por favor, assinale no número que expressa sua opinião.

Use a escala abaixo para dar suas repostas:

Marque "1", se a sentença te descreve "muito mal"

Marque "2", se a sentença te descreve "mal"

Marque "3", se a sentença te descreve "mais ou menos"

Marque "4", se a sentença te descreve "bem"

Marque "5", se a sentença te descreve "muito bem"

Pergunta: Avalie o quão bem ou mal as sentenças abaixo te descrevem profissionalmente:

\section{Itens que compõe o Fator 1 Trabalho em equipe (polo positivo).}

1. Divirto-me quando oriento atividade em grupo.

2. Empolgo-me em propor atividades que envolvam superação.

3. O sucesso dos meus alunos/atletas é positivo para mim.

4. Gosto de propor atividades de integração da equipe. 
5. Antes de agir, penso na repercussão disso com meus alunos/atletas.

6. Respeito o ponto de vista dos outros.

7. De modo geral, acredito que as pessoas têm boas intenções quando trabalham em equipe.

8. Procuro fazer com que os meus alunos/atletas se sintam bem.

9. Preocupo-me com meus alunos/atletas.

10. Nos treinos/aulas procuro achar uma melhor forma de realizar a tarefa para melhorar o desempenho dos meus alunos/atletas.

11. Procuro apoiar meus alunos/atletas quando observo-os tendo alguma dificuldade.

12. Respeito os sentimentos das pessoas.

\section{Itens que compõe o Fator 2 Excelência (polo positivo).}

1. Revejo a aula/treino quando fica muito difícil para os alunos/atletas.

2. Tenho facilidade para propor atividades com muitas regras estabelecidas.

3. Não tenho dificuldade durante a aula/treino, pois não me distraio com outras coisas.

4. Não abandono aquilo que planejo por medo de ser criticado por outros.

5. Aulas/treinos difíceis me motivam.

6. Sou cuidadoso com regras e regulamentos.

7. Tenho muita disposição para tarefas difíceis. 
8. Não tenho dificuldade para me adaptar as atividades que envolvam regras e regulamentos fixos.

9. Penso que o treino contribui para o desempenho dos meus alunos/atletas.

10. Nunca pensei em desistir de dar aula/treino.

11. Acredito que os treinos/aulas deveriam ocorrer em maior frequência.

12. Fico motivado com frequência.

\section{Itens que compõe o Fator 3 Autocontrole (polo negativo).}

1. Às vezes descumprir regras é comum no esporte.

2. Acho que é normal cometer algumas infrações para alcançar aquilo que quero.

3. Com frequência, sinto vontade de agredir algumas pessoas.

4. Quando alguém critica minha atuação, sinto vontade de xingar.

5. Frequentemente faço ameaças.

6. Frequentemente aumento o tom de voz para intimidar.

7. Eu me divirto em apontar os erros de outros profissionais.

8. Quando estou com raiva, pode acontecer que eu não cumpra regras.

9. Fico com raiva rapidamente quando algo ruim me acontece na aula/treino.

10. Se alguma pessoa me enganar, deverá receber na mesma moeda.

11. Fico irritado quando percebo más intenções das pessoas.

12. Se eu precisar descumprir alguma regra para ganhar, eu farei isso. 
PARTE 2 - ENVOLVIMENTO (adaptado de SHANK e BEASLEY, 1998)

Avalie os sentimentos que você tem com relação aos JOGOS OLÍMPICOS de 2016 do Rio de Janeiro (por favor, circule). Por exemplo, se você acha que os Jogos Olímpicos do Rio FORAM:

- totalmente CHATOS, marque 1.

- EMOCIONANTES, marque 7.

-Um pouco CHATOS e um pouco EMOCIONANTES, marque 4.

\begin{tabular}{|l|l|l|l|l|l|l|l|l|}
\hline Chatos & 1 & 2 & 3 & 4 & 5 & 6 & 7 & Emocionantes \\
\hline Desinteressantes & 1 & 2 & 3 & 4 & 5 & 6 & 7 & Interessantes \\
\hline Sem valor & 1 & 2 & 3 & 4 & 5 & 6 & 7 & Com valor \\
\hline Sem atração & 1 & 2 & 3 & 4 & 5 & 6 & 7 & Com atração \\
\hline Inúteis & 1 & 2 & 3 & 4 & 5 & 6 & 7 & Úteis \\
\hline Desnecessários & 1 & 2 & 3 & 4 & 5 & 6 & 7 & Necessários \\
\hline Irrelevantes & 1 & 2 & 3 & 4 & 5 & 6 & 7 & Relevantes \\
\hline Insignificantes & 1 & 2 & 3 & 4 & 5 & 6 & 7 & Importantes \\
\hline
\end{tabular}


PARTE 3 - ENVOLVIMENTO COM OS JOGOS OLÍMPICOS 2016 (adaptado de SHANK E BEASLEY, 1998)

1- Por favor, responda as perguntas abaixo.

1.1- Você esteve no Rio e assistiu algum jogo/competição dos Jogos Olímpicos 2016 ao vivo, no local (estádio, ginásio, arena)?

( ) Não fui.

( ) Sim, eu fui e assisti jogos/competições ao vivo.

(Condicional a "Sim") $\rightarrow$ Por favor, escreva o número de jogos/competições que você assistiu ao vivo:

1.2- Você assistiu algum jogo/competição dos Jogos Olímpicos 2016 pela TV?

( ) Não assisti.

( ) Sim, eu assisti a jogos/competições pela TV.

(Condicional a "Sim") $\rightarrow$ Aproximadamente, quantas horas por dia você passava assistindo aos Jogos Olímpicos Rio 2016:

1.3- Durante os Jogos Olímpicos Rio 2016, você usou a internet para assistir jogos/competições, para assistir vídeos, ou para ler notícias sobre os Jogos?

( ) Não usei.

( ) Sim, usei a internet para isto.

(Condicional a "Sim") $\rightarrow$ Aproximadamente, quantas horas por dia você usava a internet para assistir jogos/competições, assistir vídeos, ou ler notícias referentes aos Jogos Olímpicos Rio 2016: 


\section{PARTE 4 - INFORMAÇÕES DEMOGRÁFICAS}

1- Como você avalia o seu nível atual de participação em esportes/exercícios físicos?

1.Eu não pratico exercício

2. Muito baixo

3. Baixo

4. Moderado

5. Alto

6. Muito alto

2- Qual é a sua idade?

3- Qual é o seu sexo?

4- Qual é a sua situação profissional?

( ) Sou estudante de Educação Física e/ou Esporte

( ) Sou profissional formado em Educação Física e/ou Esporte

( ) Sou estudante de outra área

( ) Sou profissional formado em outra área 
5- Qual é seu estado civil?

( ) Solteiro(a)

( ) Casado(a)

( ) Separado(a)/ Divorciado(a)

( ) Viúvo(a)

6- Qual é a renda média da sua família em salários mínimos (SM)?

$(1 \mathrm{SM}=\mathrm{R} \$ 937,00)$

( ) Até $5 \mathrm{SM}$

( ) De 6 a $10 \mathrm{SM}$

( ) De 11 a 15 SM

( ) De 16 a $20 \mathrm{SM}$ 